\title{
Toxicology Studies on Lewisite and Sulfur Mustard Agents: Two-Generation Reproduction Study of Lewisite in Rats
}

\section{Final Report}

L. B. Sasser, J. A. Cushing, D. R. Kalkwarf, P. W. Mellick and R. L. Buschbom

Pacific Northwest Laboratory, P.O. Box 999

Richland, WA 99352-0999

July 15,1989

Supported by

U.S. Army Medical Research and Development Command

Fort Detrick, Frederick, MD 21701-5012

Army Project Order No. 84PP4865

Contracting Officer's Representative:

Jack C. Dacre, Ph.D., D.Sc.

Health Effects Research Division

U.S. Army Biomedical Research and Development Laboratory

Fort Detrick, Frederick, MD 21701-5010

Approved for public release; distribution unlimited

The findings in this report are not to be construed as an official Department of the Army position unless so designated by other authorized documents. 


\title{
DISCLAIMER
}

This report was prepared as an account of work sponsored by an agency of the United States Government. Neither the United States Government nor any agency thereof, nor Battelle Memorial Institute, nor any or their employees, makes any warranty, expressed or implied, or assumes any legal liability or responsibility for the accuracy, completeness, or usefulness of any information, apparatus, product, or process disclosed, or represents that its use would not infringe privately owned rights. Reference herein to any specific commercial product, process, or service by trade name, trademark, manufacturer, or otherwise does not necessarily constitute or imply its endorsement, recommendation, or favoring by the United States Government or any agency thereof, or Battelle Memorial Institute. The views and opinions of authors expressed herein do not necessarily state or reflect those of the United States Government or any agency thereof.

\author{
PACIFIC NORTHWEST LABORATORY \\ operated by \\ BATTELLE MEMORIAL INSTITUTE \\ for the \\ UNITED STATES DEPARTMENT OF ENERGY \\ under Contract DE-AC06-76RLO 1830
}




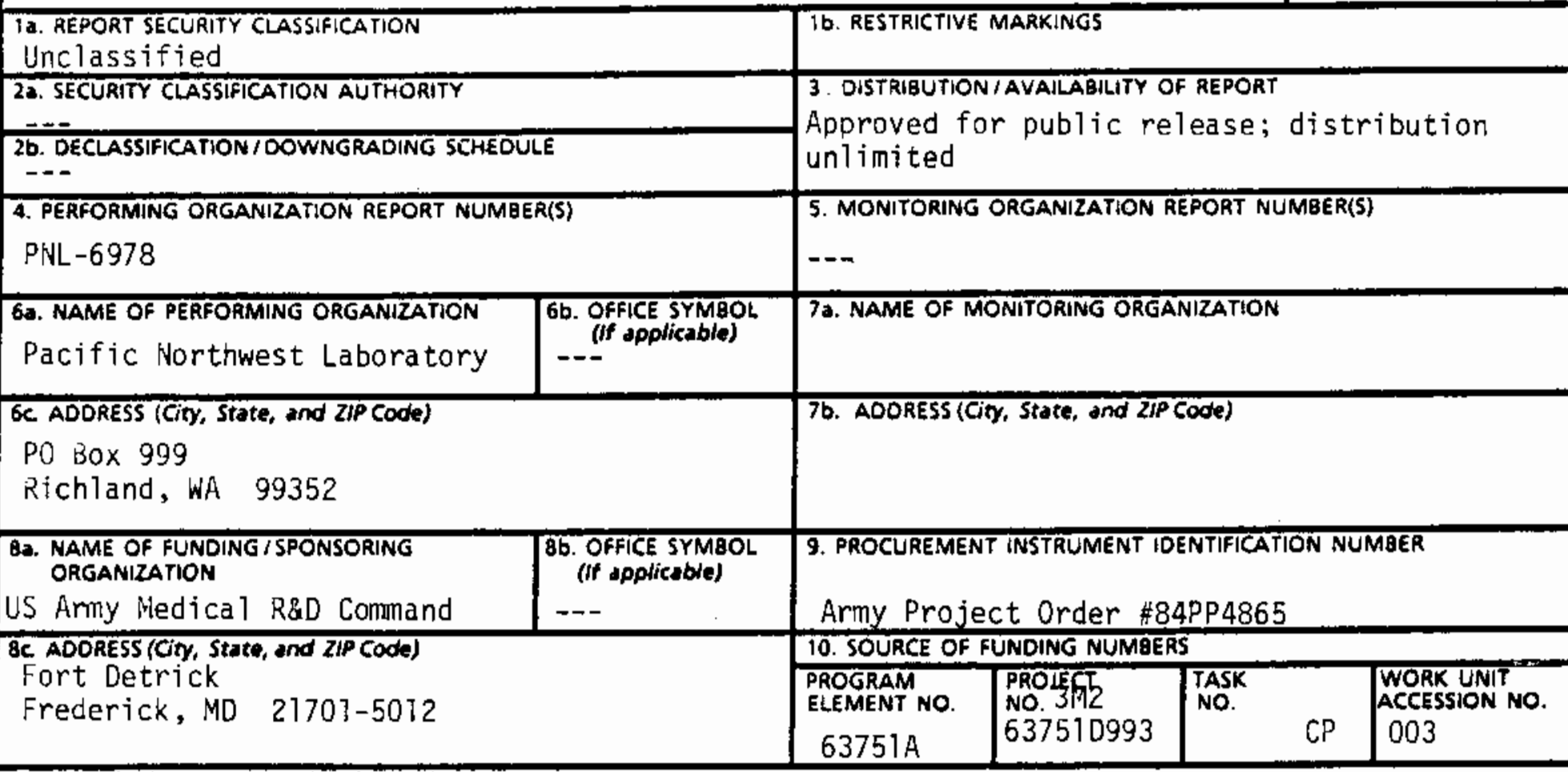

\section{TITLE (Indude Security Classification)}
(U) Toxicity Studies
on Lewisite and Sulfur Mustard Agents

12. PERSONAL AUTHOR(S)

L.B. Sasser, J.A. Cushing, D.R. Kalkwarf, P.W. Mellick, and R.L. Buschbom

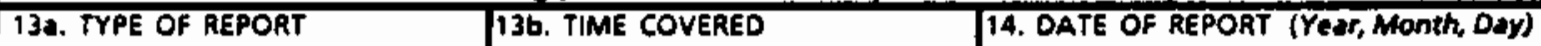

Fina $]$ FROM $9-14-84$ TO $7-15-89 \quad 1989$ July 15

15. PAGE COUNT

16. SUPPLEMENTARY NOTATION

Two-Generation Reproduction Study of Lewisite in Rats Aonendices available on request from USABRDI as a separate volume

\begin{tabular}{|c|c|c|l}
\hline 17. & COSATI COOES & 18. SUBJECT TERMS (Continue on reverse if necessary and identify by bjock number) \\
\hline FIELO & GROUP & SUB-GROUP & Lewisite, Reproduction, Toxicity, In Vitro Tests, Rats, RA5 \\
\hline 24 & 07 & &
\end{tabular}

19. ABSTRACT (Continue on reverse if neceswry and identify by block number)

0ccupational health standards have not been established for Lewisite [bis(2-chlorethy1)arsine], a potent toxic vesicant which reacts with the sulfhydryl groups of proteins through its arsenic group. The purposes of this study were to detemine the reproductive consequences and dose-response of continuing Lewisite exposure of parental males and females and their offspring in a 42-week two-generation study.

Solutions of Lewisite were prepared for administration by diluting the neat agent with sesame oil. Rats were administered Lewisite $(0,0.10,0.25$ or $0.60 \mathrm{mg} / \mathrm{kg} / \mathrm{day}$ for 5 days a week) via intragastric intubation prior to mating, during mating and after mating until the birth of their offspring. The dams continued to receive Lewisite during lactation. At weaning, male and female offspring of each group were selected to continue on the

\section{DISTRIBUTION/AVAILABILITY OF ABSTRACT $\quad$ 21. ABSTRACT SECURITY CLASSIFICATION XUNCLASSIFIEDIUNLIMITED $\square$ SAME AS RPT. $\square$ DTIC uSERS UnClassifjed}

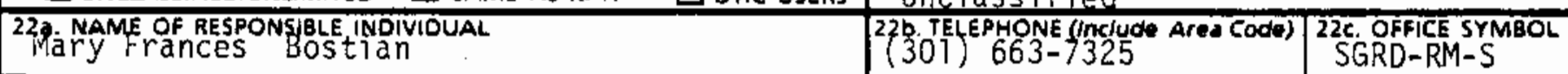


study; receiving Lewisite during adolescence, mating and throughout gestation. Again, the dams continued to receive Lewisite until weaning of the offspring.

Lewisite had no adverse effect on reproduction perfomance, fertility or reproductive organ weights of male or female rats through two consecutive generations. No adverse effect to offspring were attributed to Lewisite exposure. Minor changes in growth was the only maternal effect observed. Lewisite exposure of parental rats caused no gross or microscopic lesions in testes, epididymis, prostrate, seminal vesicles, ovaries, uterus or . vagina. Severe inflammation of the lung was observed at necropsy in cases in which Lewisite gained access to the respiratory system from accidental dosing or reflux and aspiration; this usually caused early death of the animal. The NOEL for reproductive effects in this study was greater than $0.60 \mathrm{mg} / \mathrm{kg} / \mathrm{day}$. 
Opinions, interpretations, conclusions and recommendations are those of the author and are not necessarily endorsed by the U.S. Army.

Where copyrighted material is quoted, permission has been obtained to use such material.

Where material from documents designated for limited distribution is quoted, permission has been obtained to use the material.

$1 B 2$ citations of commercial organizations and trade names in this report do not constitute an official Department of the Army endorsement or approval of the products or services of these organizations.

If In conducting research using animals, the investigator(s) adhered to the "Guide for the Care and Use of laboratory Animals," prepared by the Committee on Care and Use of laboratory Animals of the Institute of Laboratory Animal Resources, National Research Council (NIH Publication No. 86-23, Revised 1985).

For the protection of human subjects, the investigator(s) have adhered to policies of applicable Federal Law 45CFR46.

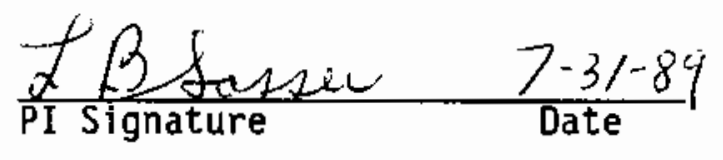


' 


\section{EXECUTIVE SUMMARY}

Chemical warfare agents present an obvious risk to individuals suffering acute exposure, but they may also present long-term environmental or occupational health hazards for workers in operations involving these chemical agents. Occupational health standards have not been established for Lewisite (L) [dichioro(2-chlorovinyl)arsine] a potent vesicant which reacts with sulfhydryl groups of proteins through its arsenic group. Lewisite is used in a number of research laboratories, stored in depot sites throughout the country and occasionally transported to distant sites. The destruction of current stockpiles of Lewisite by the U.S. Army in the near future could create additional environmental and occupational risk. To establish a database for setting environmental and occupational standards, we conducted studies to evaluate the toxicity, mutagenicity, and reproductive effects of Lewisite using in vitro and in vivo study systems. The purposes of this multi-generation study were to determine the reproductive consequences and dose-response of continuing chemical exposure of parental males and females and their offspring in a 42 week two-generation study.

Lewisite was administered to three groups of male and female rats prior to mating, during mating, and after mating until birth of the offspring at which time the male rats were sacrificed. The dams continued to receive Lewisite during lactation. At weaning, male and female offspring ( $F_{1}$ ) of each group were randomly selected to continue on the study; receiving Lewisite during adolescence, mating, and throughout gestation. Again, the parental males were sacrificed at birth of the offspring and the parental females continued to receive Lewisite until weaning of the $F_{2}$ offspring at 3 weeks of age. A fourth group of male and female rats received sesame oil and served as the vehicle controls. Twenty male and 25 female rats were assigned to each of treatment groups and to the vehicle control group for each generation.

Intragastric administration of Lewisite at levels of $0.10,0.25$, and $0.60 \mathrm{mg} / \mathrm{kg} /$ day had no adverse effect on reproductive performance, fertility or reproductive organ weights of male and female rats through two consecutive 
generations. Likewise, no adverse effects to offspring were attributed to Lewisite exposure. Minor changes in growth was the only maternal effect observed among survivors. For both $F_{0}$ and $F_{1}$ females, the overall growth curve shows that growth was reduced significantly in the $0.25 \mathrm{mg} / \mathrm{kg}$ groups as compared to controls. In addition this response appeared to be stronger for the 0.25 than the $0.60 \mathrm{mg} / \mathrm{kg}$ group, but the low number of surviving animals in the $0.60 \mathrm{mg} / \mathrm{kg}$ group may have skewed the results. There were no significant changes on reproductive organ weights.

Daily intragastric administration of $0.60 \mathrm{mg} / \mathrm{kg}$ of Lewisite to parental rats in the $F_{0}$ and $F_{1}$ generation caused no gross or microscopic lesions in testes, epididymis, prostate, seminal vesicles, ovaries, uterus, or vagina. No target organ was identified by gross examination of all organs at necropsy or by histologic examination selected tissues. In cases in which the test material gained access to the respiration system by either an accident in dosing or by reflux and aspiration, severe inflammation of lung resulted which usually caused death of the affected animal.

The No-Observable Effect-Level for reproductive effects in this study was greater than $0.60 \mathrm{mg} / \mathrm{kg}$. However, Lewisite was highly toxic and it is doubtful that greater doses could be studied by the intragastric route of exposure because of the sensitivity of the upper respiratory tract and the resulting high maternal mortality. 


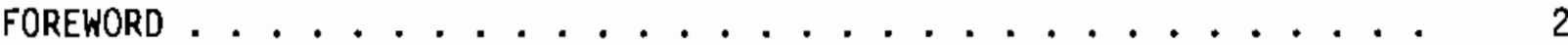

EXECUTIVE SUMMARY. . . . . . . . . . . . . . . . . 4

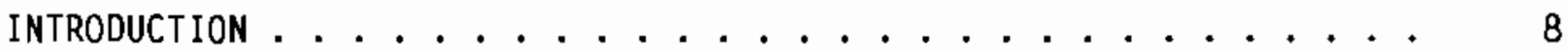

MATERIALS AND METHODS. . . . . . . . . . . . . . . 12

LEWISITE. . . . . . . . . . . . . . . 12

Procurement and Characterization ........... 12

Selection and Characterization of the Diluent. ...... 12

Preparation of Solutions for Administration. ........ 13

Analyses of Lewisite Solutions .............. . 14

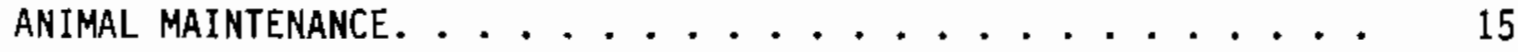

Experimental Design................ 17

Administration of Lewisite . . . . . . . . . . . 18

Mating Procedures................. 19

Procedures for Newborn Pups ............ . . 20

Necropsy and Histological Evaluations. . . . . . . . . 20

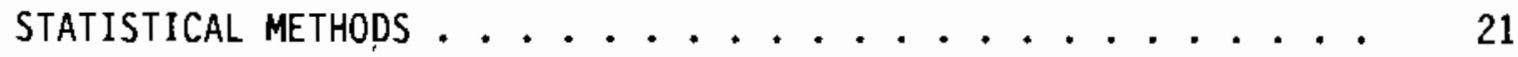

RESULTS ................................. 22

Necropsy and Histological observation......... 28

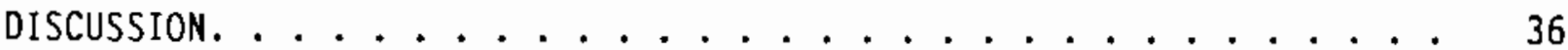

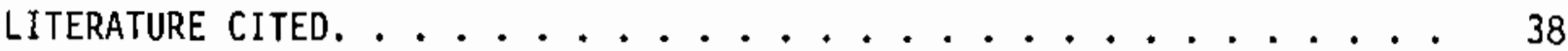

STUDY DATES ............................. 40

PERSONNEL LIST. ......................... 41

QUALITY ASSURANCE STATEMENT . . . . . . . . . . . . . 42

DISTRIBUTION. ........................ 43

(See separate report part 2)

A. SUMMARY OF REPRODUCTIVE RESULTS FOR FO AND F1 RATS ....... A-1

B. PATHOLOGY REPORT ................ B-1 
1. Experimental design. ............... 17

2. Body weights of $F_{0}$ male and female rats gavaged with Lewisite. . 25

3. Body weights of $F_{1}$ male and female rats gavaged with Lewisite. . 26

\section{LIST OF TABLES}

1. Relevant chemical and physical data for Lewisite, Dichloro(2-chlorovinyl)arsine............. 9

2. $L 0_{58}$ values for Lewisite of various routes of administration . . 10

3. Analysis of sesame oil for peroxide. . . . . . . . . 14

4. Lewisite concentration of dosing solutions analyzed for the

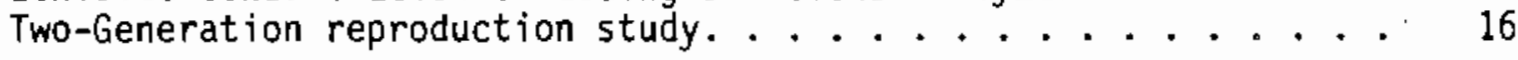

5. Treatment groups of the Lewisite Two-Generation reproduction study .................

6. Body weights $(g)$ of $F_{0}$ male and female rats exposed to Lewisite. . . . . . . . . . . . . .

7. Body weights $(\mathrm{g})$ of $\mathrm{F}_{1}$ male and female rats exposed to Lewisite. . . . . . . . . . . . .

8. Reproductive performance of $F_{0}$ and $F_{1}$ rats exposed to

Lewisite . . . . . . . . . . . . . . .

9. Birth and measurements of $F_{D}$ and $F_{1}$ females exposed to Lewisite during pregnancy. . . . . . . . . . . 29

10. Growth of $F_{1}$ and $F_{2}$ male and female pups during nursing. .... 30

11. Body and reproductive organ weights at schedule necropsy of $F_{0}$ and $F_{1}$ male rats exposed to Lewisite. .......... 31

12. Body and reproductive organ weights at schedule necropsy of $F_{0}$ and $F_{1}$ female rats exposed to Lewisite. . . . . . . . 32

13. $F_{0}$ and $\mathrm{F}_{1}$ female and male rats examined histologically ..... 34 


\section{INTRODUCTION}

Chemical warfare agents present an obvious risk to individuals suffering acute exposure but they may also present long-term environmental or occupational health hazards for workers in operations involving these chemical agents. Lewisite [dichloro(2-chlorovinyl) arsine], one of two major vesicant agents, presents a potential for accidental or occupational exposure because it is used in a number of research laboratories, stored in depot sites throughout the country and occasionally transported to distant sites. In addition, stockpiles of Lewisite are scheduled for destruction by the U.S. Army in the near future, creating an additional potential for environmental and occupational exposure. Although considerable information is known concerning the acute effects of Lewisite, few data are available on its longterm hazards. Segments of the population that may be particularly sensitive to its toxicity include the chronically $i 11$, the young and old, and the unborn. It is this concern that has prompted these studies to identify the potentially toxic, mutagenic and reproductive effects of Lewisite and to establish a database for the development of hazard evaluations and occupational health standards for this chemical.

Lewisite is a highly toxic chemical vesicant. Unlike the strong alkylating vesicant sulfur mustard, Lewisite reacts with the sulfhydryl groups of proteins through its arsenic group (Cassarett and Doul1, 1986). In the presence of water or alkalies, Lewisite hydrolyzes to form Lewisite oxide, which is non-volatile and insoluble in water. Although few data are available, Lewisite oxide is generally thought to be a weaker vesicant (Gates et a1. 1946) but its toxicity has yet to be comprehensively studied. Relevant chemical and physical data for Lewisite are summarized in Table 1.

A comprehensive review which summarized the chemical and toxicity data of Lewisite acquired during World War I and World War II was published in 1946 (Gates, et a1. 1946). This review compared known human and animal data and concluded that sufficient toxicologic data were available for the determination of military usage. Lewisite exposure is characterized by immediate onset of pain, unlike the action of sulfur mustard in which pain may be delayed. The mucus membranes of the respiratory and gastrointestinal 
TABLE 1. Relevant Chemical and Physical Data for Lewisite, Dichloro(2-Chlorovinyl) arsine*

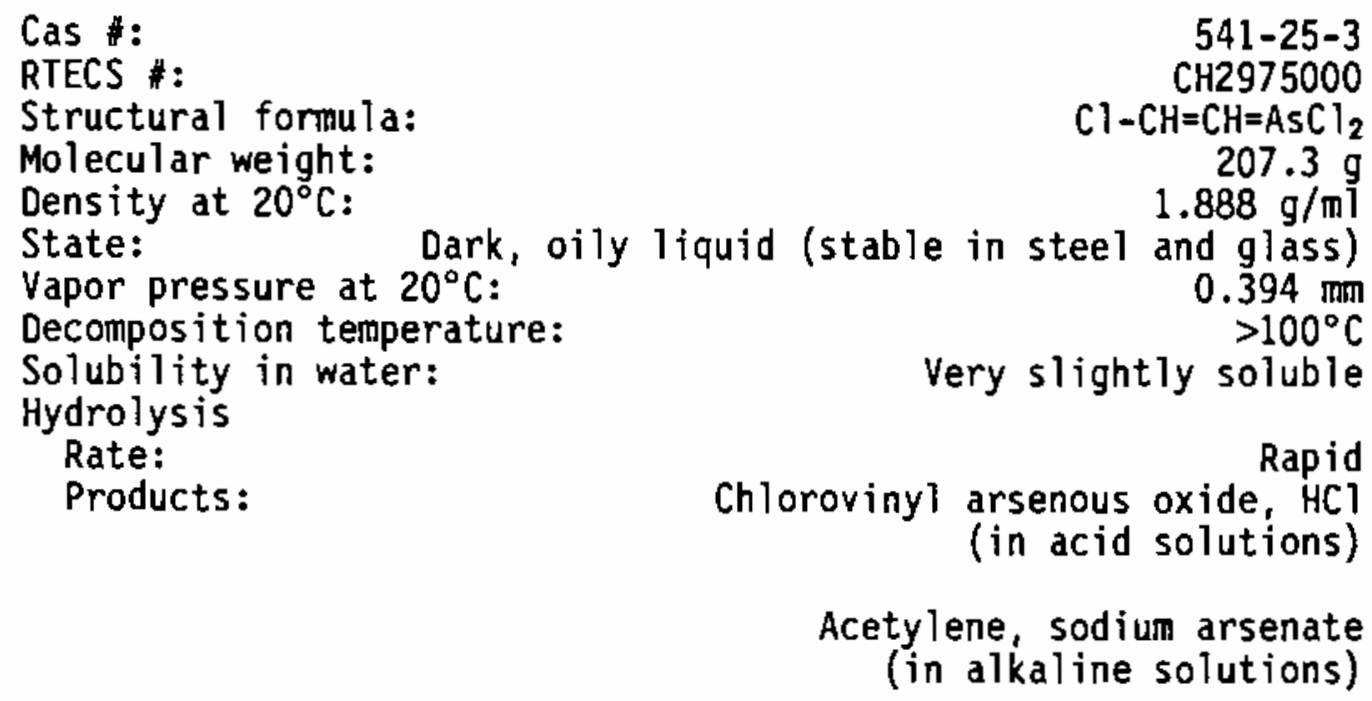

$0.394 \mathrm{~mm}$ $>100^{\circ} \mathrm{C}$

Very slightly soluble

Rapid

Chlorovinyl arsenous oxide, $\mathrm{HCl}$

(in acid solutions)

Acetylene, sodium arsenate

(in alkaline solutions)

*Rosenblatt et al. 1975

tracts are particularly sensitive to Lewisite damage. Lewisite is not only a lethal vesicant but is also a systemic toxin; the liver, kidneys, gall bladder, bile duct and other organ systems are vulnerable to damage if absorption occurs (Cameron et al. 1946).

Exposures to Lewisite vapor products edema of the respiratory tract and accumulation of pleural fluid (Gates, et al., 1946). Skin lesions resulting from contact with liquid Lewisite involve the rapid formation of an erythematous area, subsequent vesication and penetration of subcutaneous tissue so that edema and necrosis are evident. Man was less sensitive to skin lesion induction than the dog or rabbit. Systemic intoxication was evident in the dog a few hours following application of Lewisite (Gates et al., 1946). Although sufficient anatomical lesions to characterize the immediate cause of death were not apparent, it was reported that fluid losses due to changes in capillary permeability did cause remarkable decreases in blood volume. Comparisons of toxic effects of Lewisite and sulfur mustard in dogs and rabbits indicated that Lewisite was more damaging to the skin and was more likely to induce systemic poisoning than was sulfur mustard. The 
acute $L_{56}$ of Lewisite administered via different exposure routes to the rat, rabbit and guinea pig are presented in Table 2 .

Table 2. LD Values for Lewisite by Various Routes of Adfifinistration*

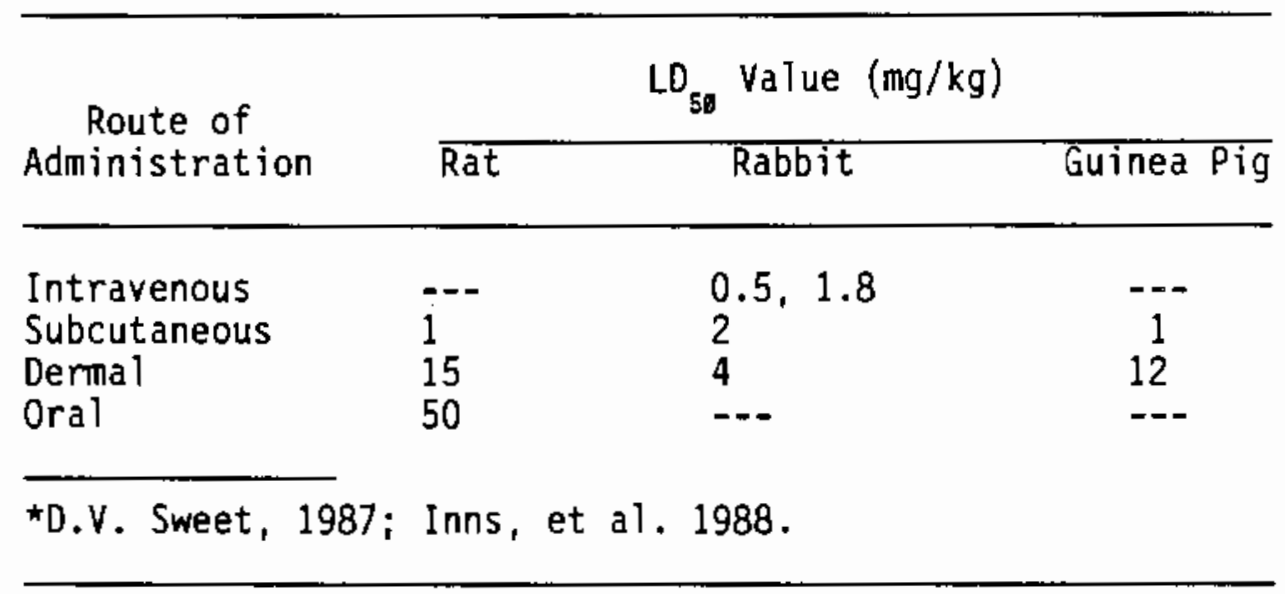

Little data are available to evaluate the potential chronic effects of Lewisite other than infomation based on anecdotal evidence from war use. Based on one incident of accidental exposure to a soldier's leg, Lewisite is considered a suspect carcinogen in man (Krause and Grussendorf, 1978). Workers of a Japanese factory producing mustard and Lewisite agents during World War II had a high mortality rate due to respiratory and gastrointestinal cancers (Wada et a1., 1968; Yamakido et al., 1985). These workers were potentially exposed to unknown quantities of both sulfur mustard and Lewisite, therefore it is not possible to implicate Lewisite as a carcinogen because sulfur mustard is a known carcinogen.

Data on the mutagenicity of Lewisite in the literature is limited. Auerbach (1947) found no mutagenic response in the fruit fly exposed to Lewisite and Loveless (1951) reported nomal cellular division in root tips exposed to aqueous solutions of Lewisite. Mutagenicity was not detected in recent studies using Ames and Chinese hanster ovary cell assays. (Stewart et a1., 1989; Jostes et al., 1989). The teratogenic potential of Lewisite was studied by Hackett et al. (1987) in rats and rabbits using a segment II teratology protocol. Rats were exposed to $0.5,1.0$ or $1.5 \mathrm{mg} / \mathrm{kg}$ Lewisite via gastric intubation from 6 to 15 days of gestation (dg) and fetuses were 
examined on $\mathrm{dg} 20$. No evidence of a teratogenic response to Lewisite was observed. Likewise, fetal development of the rabbit exposed to 0.07 to 0.6 $\mathrm{mg} / \mathrm{kg}$ Lewisite between 6 and $19 \mathrm{dg}$ was not affected even though maternal mortality was induced. These results suggest that Lewisite is not teratogenic in the rat or the rabbit after short term exposures since fetal effects were observed only at dose levels that induced maternal toxicity.

It is of interest that many of the symptoms of Lewisite and arsenic intoxication are similar (severe inflammation of the gastrointestinal tract with electrolyte disturbances and ulceration and perforation of membranes) (NAS, 1977) and raises the possibility that the systemic toxicity of Lewisite may result from its arsenic group. In alkaline solutions, Lewisite may hydrolyze to form acetylene and sodium arsenate. Leonard and Lauwerys (1980) reviewed the carcinogenicity, teratogenicity and mutagenicity of a wide variety of arsenic compounds. Some arsenic compounds were mutagenic in bacterial systems while others were not. In general all arsenic compounds tested in mammalian cell systems produced chromosomal aberrations, but no information is available for mutation induction in in vitro mamalian systems. Arsenic, as sodium arsenate or arsenite, is known to be embryotoxic and teratogenic in a number of animal species (Leonard and Lauwerys, 1980). In a comparison of Lewisite and sodium arsenite toxicity in the rabbit following intravenous administration, Inns et al. (1988) reported that the $\mathrm{LD}_{50}$ values for sodium arsenite and Lewisite were not similar (7.6 and 1.8 $\mathrm{mg} / \mathrm{kg}$, respectively). Furthermore, significant differences in tissue arsenic content and pathology were reported for the two chenicals. Hackett et al. (1987) estimated that the arsenic uptake and accumulation from Lewisite exposure to maternal animais and their fetuses would not be significant at non-lethal doses in short-term teratology studies. However, arsenic accumulation may be important in long-term exposures.

Comprehensive data are not available to evaluate the potential risk to reproduction from long-term occupational exposure to Lewisite. The purposes of this multi-generation study were to determine the reproductive consequences and dose-response of continuing chemical exposure of parental males and females and their offspring in a 42 week two-generation study. 


\section{MATERIALS AND METHODS}

\section{LEWISITE}

Procurement and Characterization

A shipment of $25 \mathrm{ml}$ of dichloro(2-chlorovinyl)arsine (Lewisite, Agent L) was received from the U.S. Army Medical Research Institute of Chemical Defense (USAMRICD) on 7 March 1985. The chemical (Lot No. L-U-4273-CTF-N) was prepared by distillation on 30 September 1984 at the Chemical Research and Development Center (CRDC). The agent was analyzed by nuclear magnetic resonance ( $\mathrm{H}-1$ and $\mathrm{C}-13$; CROC SOP No. 8-1-83-1, Annex $\mathrm{F}$ ) at the Research Directorate, CRDC. Results of the analyses, expressed as calculate weight percent, were 95.8 and 4.0 for trans and cis isomers of dichloro(2chlorovinyl)arsine, respectively, and 0.2 for unknown compounds.

The Lewisite was divided into two equal portions, pipetted into $30-\mathrm{ml}$ Wheaton vials, sealed and stored in secondary unbreakable containers in refrigerated storage at $\sim 6^{\circ} \mathrm{C}$. To comply with Good Laboratory Practices requirements, PNL requested that USAMRICD retain an aliquot of this lot of Lewisite.

Lewisite was analyzed on 20 January 1986 to detect the presence of common impurities, such as Lewisite oxide and the cis-trans isomers of bis(2chlorovinyl)chloroarsine and tris(2-chlorovinyl)arsine (Rosenblatt et al., 1975). Measurement of the ultraviolet absorption spectrum of the sample in isooctane revealed that the spectrum and the absorptivity of the material at $215 \mathrm{~nm}$ agreed with published values in the literature (Rewick, et al., 1986; Mohler and Sorge, 1939) and did not indicate the presence of ultravioletabsorbing compounds other than Lewisite. This conclusion was supported by results from gas-chromatographic analyses of the sample following derivatization with 2-mercaptoethanol.

\section{Selection and Characterization of Diluent}

Lewisite is relatively insoluble and also is rapidiy hydrolyzed in water, therefore sesame oil was employed as the diluent for dosing solutions in this study. This selection was not only based on the chemical and 
physical properties of the compound, but also on the lack of a toxic response of the vehicle when introduced into the stomach of the animal. Corn oil is commonly the vehicle used for the administration of water-insoluble compounds; however, Hackett et al. (1987) reported from data in the literature that corn oil may not be appropriate for reproductive studies because of its high steroid content and recommended using sesame oil in their studies of the teratology of Lewisite. Sesame oil contains no preservatives, appears to be stable when stored under proper conditions, is relatively low in steroids and is readily available.

The sesame oil (Hain Pure Food Company, Los Angeles, $C A$ ) used in this study was purchased locally in one quart bottles and numbered according to lot and bottle. Peroxide analyses of each lot of sesame oil was performed at the beginning of the study or when purchased and periodically throughout the study to provide a measure of oxidation as an indication of rancidity of the oil. The method measures the ability of the oil to oxidize aqueous iodide. Only oil in which the peroxide content was less than $10 \mathrm{meq} / \mathrm{kg}$ was used in the study.

The results of the peroxide analyses of the sesame oil used are given in Table 3. The amount of peroxide in the sesame oil was well within the acceptable limits of $10 \mathrm{meq} / \mathrm{kg}$ set forth in the protocol.

\section{Preparation of Solutions for Administration}

The Lewisite dosing solutions administered to the animals were prepared in advance, approximately every two weeks, and stored in a refrigerator at approximately $6^{\circ} \mathrm{C}$. We have previously found that Lewisite is stable in sesame oil for at least 2-3 weeks when stored under these conditions. The general procedure was to determine in advance the amount of neat Lewisite needed, based on the volumes to be prepared and the final concentrations desired. This volume was then removed from the bottle of neat Lewisite and thoroughiy mixed into a known volume of sesame oil. Aliquots of this intermediate concentration were then diluted further to give the final concentration needed for the dosing solutions. Aliquots of the final solutions were placed in wheaton bottles with teflon-lined sepa and aluminum caps. Each wheaton bottle contained sufficient volume of Lewisite-sesame oil 
TABLE 3. Analysis of Sesame $0 i 1$ for Peroxide

\begin{tabular}{llccc}
\hline Lot No. & Date Purchased & Assay Date & $\begin{array}{c}\text { Container } \\
\text { Identification }\end{array}$ & $\begin{array}{c}\text { Peroxide } \\
\text { meq/kg }\end{array}$ \\
\hline $51564-6$ & $10 / 06 / 86$ & $03 / 02 / 87$ & 11 & 8.1 \\
$51565-09$ & $03 / 04 / 87$ & $03 / 13 / 87$ & 3 & 6.8 \\
& & $05 / 01 / 87$ & 12 & 7.9 \\
$51566-30$ & $04 / 10 / 87$ & $05 / 01 / 87$ & 5 & 2.3 \\
& & $06 / 29 / 87$ & 12 & 2.6 \\
$51566-38$ & $06 / 16 / 87$ & $06 / 29 / 87$ & 2 & 0.8 \\
& & $11 / 24 / 87$ & 12 & 0.7 \\
$51566-55$ & $08 / 31 / 87$ & $11 / 24 / 87$ & 2 & 3.6 \\
& & $11 / 24 / 87$ & 12 & 0.9 \\
\hline $51566-69$ & $11 / 13 / 87$ & $11 / 24 / 87$ & 1 & \\
\hline
\end{tabular}

for 1 day's use. The bottles were labeled with the name and the concentration of the agent (Lewisite) and placed into a secondary unbreakable container which was identified by chemical name, concentration, lot number and date prepared.

\section{Analyses of Lewisite Solutions}

Lewisite in sesame oil was assayed by gas chromatography, using a capillary column and flame-ionization detection. Substantial analytical problems were encountered during our initial studies (dose-range and teratology studies in rats), and the procedure was subsequently modified for analyses of the solutions used in this study. The presence of high-boiling components in the sesame oil required that the temperature of the capillarycolumn inlet be maintained at $200^{\circ} \mathrm{C}$. Since the decomposition temperature for Lewisite is low $\left(190^{\circ} \mathrm{C}\right)$, it was necessary to develop an assay that would permit the migration of sesame oil through the column without any decomposition of the Lewisite. To solve this problem, a stable derivative of 
Lewisite in sesame oil was prepared by the addition of 2-mercaptoethanol. The reaction, which proceeds at room temperature, may be written:

$$
\mathrm{ClCH}=\mathrm{CHASCl}_{2}+2 \mathrm{HSCH}_{2} \mathrm{CH}_{2} \mathrm{OH} \rightarrow \mathrm{ClCH}=\mathrm{CHAS}\left(\mathrm{SCH}_{2} \mathrm{CH}_{2} \mathrm{OH}\right)_{2}+2 \mathrm{HCl}
$$

In the procedure developed for the analysis, Lewisite samples with concentrations $\leq 2.0 \mathrm{mg} / \mathrm{ml}$ were diluted $1: 10$ with isooctane prior to analysis. For the assay, $0.5 \mathrm{ml}$ of the sample was diluted with $0.5 \mathrm{ml}$ of a solution containing $120 \mathrm{ng}$ of 1-chloronaphthalene and $5584 \mathrm{ng}$ of 2-mercaptoethanol/ $\mu 1$ in isooctane contained in a $1.5 \mathrm{ml}$ automatic sampler vial with a Teflonlined, crimped-top cap. The column (J\&H Scientific, DB-5) temperature program was $80^{\circ} \mathrm{C}$ for $\mathrm{t} \min \left(5^{\circ} / \mathrm{min}\right)$ to $140^{\circ} \mathrm{C}, 20^{\circ} / \mathrm{min}$ to $300^{\circ} \mathrm{C}$ and $300^{\circ} \mathrm{C}$ for 20 min. A Hewlett-Packard ${ }^{\circ} 5840 \mathrm{~A}$ gas chromatograph and a $7672 \mathrm{~A}$ automatic sample changer were used.

The results of the analyses for Lewisite in the five solutions selected for analysis are shown in Table 4. The results were within acceptable limits of analytical error $( \pm 10 \%$ ) for all five samples of the $0.36 \mathrm{mg} / \mathrm{ml}$ concentration and for most concentrations prepared and analyzed in the final phase of the study. The method was not sufficiently sensitive to evaluate the 0.15 or $0.06 \mathrm{mg} / \mathrm{ml}$ concentrations during the early phase of the study. The probable cause for the lack of sensitivity at the low concentrations may be interference by some constituents of the sesame oil.

\section{ANIMAL MAINTENANCE}

Four week old male and female rats of Sprague-Dawley derivation were obtained from Charles River Laboratories, Inc., Raleigh, NC facility and quarantined in isolation for about 3 weeks until a health evaluation was completed. The Sprague-Dawley rat was selected because it has been used in a number of previous reproductive studies at PNL including gavage studies of Lewisite thereby providing information for dose estimation. During quarantine the rats were group housed, separated by sex, in stainiess-steel wire bottom cages placed on automatic flush racks with an automatic watering system. 
The environmental conditions specified for the animal rooms were temperatures of $72 \pm 3^{\circ} \mathrm{F}$, relative humidity of $50 \pm 15 \%$, and a lighting cycle of 12 hours on and 12 hours off. Certified Rodent Chow (\#5002) was purchased from Purina and drinking water were provided ad libitum. Drinking water supplied to the animal rooms was passed through a reverse-osmotic purification unit and containing two particle filters and a carbon filter.

Table 4. Lewisite (L) Concentration of Dosing Solutions Analyzed Study for Two-Generation Reproduction Study

\begin{tabular}{lcccc}
\hline $\begin{array}{c}\text { Date } \\
\text { Prepared }\end{array}$ & $\begin{array}{c}\text { Date } \\
\text { Analyzed }\end{array}$ & $\begin{array}{c}\text { Dose Level } \\
(\mathrm{mg} / \mathrm{kg})\end{array}$ & $\begin{array}{c}\text { L Concentration }(\mathrm{mg} / \mathrm{m}) \\
\text { Theoretical }\end{array}$ \\
\hline $02 / 19 / 87$ & $02 / 23 / 87$ & 0.60 & 0.36 & $0.34 \pm 0.02$ \\
& & 0.25 & 0.15 & $0.076 \pm 0.03$ \\
& 0.01 & 0.06 & $0.019 \pm 0.001$ \\
& $03 / 10 / 87$ & 0.60 & 0.36 & $0.310 \pm 0.06$ \\
$04 / 15 / 87$ & $04 / 22 / 87$ & 0.60 & 0.36 & $0.38 \pm 0.02$ \\
& & 0.25 & 0.15 & $0.041 \pm 0.0$ \\
$07 / 08 / 87$ & 0.01 & 0.06 & $0.003 \pm 0.0005$ \\
& $07 / 08 / 87$ & 0.60 & 0.36 & $0.35 \pm 0.007$ \\
& & 0.25 & 0.15 & $0.15 \pm 0.002$ \\
$11 / 03 / 87$ & $11 / 06 / 87$ & 0.01 & 0.06 & $0.04 \pm 0.001$ \\
& & 0.60 & 0.36 & $0.35 \pm 0.01$ \\
& & 0.25 & 0.15 & $0.072 \pm 0.006$ \\
$11 / 17 / 87$ & $11 / 18 / 87$ & 0.01 & 0.06 & $0.052 \pm 0.005$ \\
& & 0.60 & 0.36 & $0.35 \pm 0.01$ \\
& & 0.25 & 0.15 & $0.150 \pm 0.002$ \\
& & 0.01 & $0.057 \pm 0.002$
\end{tabular}

* Mean \pm SE

Near the end of quarantine, 10 rats were subjected to a health evaluation and tested for antibodies to viral pathogens. No significant pathogens or lesions were found. 
Following isolation the rats were weighed and assigned to the appropriate treatment groups by sex and weight by means of a formal randomization statistical package (see Statistical Methods). Each animal was assigned an individual identification number by means of a metal ear tag. The animals were individually housed in wire bottom cages on flush racks and cage cards were used to indicate the animal number and treatment group. Prior to parturition (no later than $\mathrm{dg}$ 17) and during lactation the females were housed in solid bottom littering cages (1 litter per cage) utilizing hardwood chip bedding.

\section{Experimental Design}

The experimental design for the two-generation reproduction study is outlined in Figure 1. Lewisite was administered to three groups of male and female rats prior to mating, during mating, and after mating until birth of

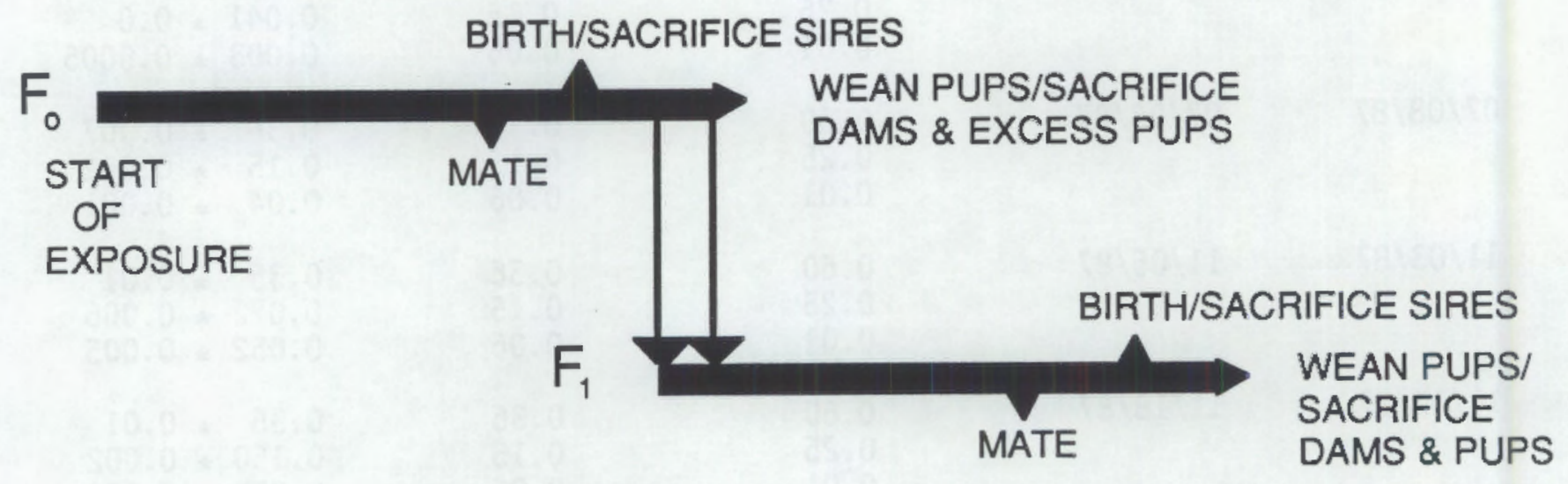

$\begin{array}{lllllllllll}0 & 4 & 8 & 12 & 16 & 20 & 24 & 28 & 32 & 36 & 42\end{array}$ WEEKS

Figure 1. Experimental Design 
the offspring at which time the male rats were sacrificed. The dams continued to receive Lewisite during lactation. At weaning, male and female offspring $\left(F_{1}\right)$ of each group were randomly selected to continue on the study; receiving Lewisite during adolescence, mating, and throughout gestation. Again, the parental males were sacrificed at birth of the $F_{2}$ offspring and the parental females continued to receive Lewisite until weaning of the offspring at 3 weeks of age. A fourth group of male and female rats received sesame oil and served as the vehicle controls. Twenty male and 25 female rats were assigned to each of treatment groups and to the vehicle control group for each generation (Table $5)$.

TABLE 5. Treatment groups of the Lewisite (L) Two-Generation Reproduction Study

Number of

Males

Number. of

Number of

Total

Dose Levels Animals

$\mathrm{F}_{0}$ Generation

L Exposure Groups

Vehicle Control

Health Screen

Females

$F_{1}$ Generation

L Exposure Groups

Vehicle Control

\section{0}

20

-.

\section{5}

25

--

25

25

\section{3}

1

-

135

45

11

\section{Administration of Lewisite}

Solutions of the appropriate concentration of sulfur mustard in sesame oil were administered to animals by intragastric intubation, 5 days per week for 13 weeks, until the beginning of the mating period. During gestation, pregnant female rats were dosed 7 days per week. Except for pregnant rats, animals were not dosed on holidays unless a minimum of 4 doses per week could not otherwise be achieved. Dose levels were calculated weekly based on the animal weight, except during pregnancy when the dose was based on the body weight at day 0 of 
gestation. Doses were administered in a constant volume of $1.67 \mathrm{ml} / \mathrm{kg}$ of body weight. Vehicle control animals were given an appropriate volume of sesame oil.

Dose levels selected for this study were based on data obtained from a dose-range study in pregnant rats, a 3 -week rat teratology study and a 90 -day subchronic study in male and female rats. A dose level of $1.5 \mathrm{mg} / \mathrm{kg}$ did not induce toxic or teratogenic responses in pregnant rats dosed for 10 days beginning on day 6 of gestation. Maternal mortality, decreased maternal and fetal body weights and a reduction in the number of viable fetuses were observed at a dose of a $2 \mathrm{mg} / \mathrm{kg}$, but no evidence of teratogenicity was observed (Hackett et al. 1987). In the 90-day subchronic study dose levels of 2.0, 1.0 and $0.5 \mathrm{mg} / \mathrm{kg}$ resulted in significant mortality in both sexes and produced lesions in the forestomach. Since it was desired to select doses such that the highest dose induced toxicity but not mortality in the $F_{0}$ animals, the low dose not produced any evidence of toxicity, and intermediate dose produce minimal observable toxic effects, dose levels were set at $0.60,0.25$ and $0.10 \mathrm{mg} / \mathrm{kg}$.

\section{Mating Procedures}

Breeding of the $F_{0}$ and $F_{1}$ adult females commenced after each generation had been gavaged with Lewisite for 13 weeks. Females were randomly matched with a male rat of the same dose group for one week; those females which did not mate during the first breeding week were reassigned to a second male and cohabited a second week. The remaining "non-pregnant" females were mated with proven males during a third breeding week. During the 21-day breeding period each female was transferred to the male cage in the late afternoon and was removed each morning and examined for the presence of sperm plugs or sperm in vaginal smears; the morning on which sperm were found was designated as day 0 of gestation. Females becoming pregnant during the 21 -day breeding period were selected for continuation in the study. Females not mating during the breeding period and all males were necropsied after the $F_{0}$ or $F_{1}$ females study animals had been selected. For $F_{1}$ matings, cohabitation of siblings was avoided. 
Procedures for Newborn Pups

Pregnant females were checked twice each day beginning on $17 \mathrm{dg}$. At birth the litters were weighed; pups were counted, sexed and examined for viability and gross abnormalities. The date of parturition was recorded and appearance and behavior of dams and pups were observed daily. On day 4 after delivery, the offspring were weighed and the litters were standardized to four male and four female pups per litter; excess pups were killed. If it were not possible to maintain an equal sex distribution within the litter because of a disproportionate sex distribution, a partial adjustment was made in order to maintain a litter size of 8 . Litters of less than 8 were not adjusted. Each pup of the litter was uniquely identified with markings on the paws with India ink. The pups were weighed again when they were 14 and 21 of days old. Pups were weaned at 21 days of age and male and female pups of the $F_{1}$ generation were randomly selected from each litter for continuation in the study; the excess pups were killed. All $F_{0}$ and $F_{1}$ adult females and the $F_{2}$ pups were killed at weaning.

Twenty male and 25 female pups within each treatment group were randomly selected from the $F_{0}$ offspring for the $F_{1}$ study. Each $F_{0}$ litter was represented by at least one male and one female unless there was a void of either sex within a litter.

\section{Necropsy and Histological Evaluations}

A complete gross necropsy was performed on all rats found dead or in moribund condition and those killed at the scheduled sacrifice. Live animals were fasted overnight, euthanitized with $70 \% \mathrm{CO}_{2}$ within one day of the last two consecutive dosings with HD and immediately necropsied. Weights of the testis, epididymis, ovary and uterus were recorded. The lungs were fixed by inserting a blunted needle into the laryngeal lumen through which the fixative was infused. The major organs were stored in $10 \%$ neutral buffered formalin (NBF) except for the testes which were fixed Bouin's solution and subsequently washed in $70 \%$ ethyl alcohol.

Histopathological evaluations were performed on reproductive organs of the high dose group and control group of the $F_{0}$ and $F_{1}$ adults. Tissues evaluated 
included vagina, uterus, ovaries, testes, seminal vesicles, prostate and epididymides.

\section{STATISTICAL METHODS}

The computer software program (DRANDBLK) for randomizing animals into experimental groups was developed by PNL and is based on a single blocking factor for animal weight. Animal weights for a given study were ordered from lightest to heaviest; blocks of animal weights were then randomly assigned to the treatment groups and the control group. Block sizes were governed by the number of test groups.

Analysis of variance was used to analyze body weight, organ weights and forestomach lesion data. When the results of the analyses were significant, Tukey's Studentized Range Test was used to delineate intergroup differences among means (Tukey, 1953). A comparisonwise error rate was set at 0.05 for Tukey's Test. An orthogonal contrast was used to test for a trend in the results repeated over time on the same animal; a randomization test was used to test for differences among growth curves (Zerbe, 1979). This test is a nonparametric statistical test that is based on the absolute area between growth curves and allows for correlation of body-weight measurements over time.

Pairwise comparison of binary response variables between groups was done by chi-square test using the P4F program in the BMDP statistical software (Dixon et al., 1983). 


\section{RESULTS}

Mortality was high among $F_{0}$ and $F_{1}$ female rats, especially those exposed to $0.60 \mathrm{mg} / \mathrm{kg}$ Lewisite. Two $F_{0}$ females (one control and one $0.60 \mathrm{mg} / \mathrm{kg}$ ) died during parturition probably as a result of breach births. The probable cause of death of three other animals was gavaging errors. The cause of most of the remaining deaths appeared to be associated with aspiration of the test material into the upper respiratory tract as previously described in a 90 -subchronic study of Lewisite (Sasser et al., 1989a). This phenomenon appeared to be more severe for the females than for males in this study.

Body weights during the pre-breeding exposure periods for surviving $F_{0}$ and $F_{1}$ rats are presented in Tables 6 and 7 . Individual weekly weights of Lewisite-treated $F_{0}$ male and female rats were not significantly different from control animals. However, the overall growth curve of the $0.25 \mathrm{mg} / \mathrm{kg} \mathrm{F} \mathrm{F}_{0}$ females was significantly reduced $(P<0.05)$ compared to the growth of the control group (Figure 2). Weekly body weights of $F_{1}$ male rats exposed to 0.25 $\mathrm{mg} / \mathrm{kg}$ Lewisite were significantly reduced compared to controls at weeks 11 and 12; weights of female rats exposed to $0.60 \mathrm{mg} / \mathrm{kg}$ were reduced at week 6 (Table 7). The overall growth curves of male and female $F_{1}$ rats administered 0.25 $\mathrm{mg} / \mathrm{kg}$ Lewisite was significantly reduced $(P<0.05)$ compared to controls (Figure 3). Although the body weights of the high dose-group was slightly depressed, there were no significant differences in the overall growth curves of treated animals compared to controls (Figure 3 ); only the 6 -week value for females $(0.60 \mathrm{mg} / \mathrm{kg})$ was significantly different $(P<0.05)$ from the control group (Table 7 ).

Breeding performance during the 3-week lavaging period was not adversely affected by exposure to Lewisite for either $F_{0}$ or $F_{1}$ animals (Table 8). Female fertility (the number of females delivering a litter expressed as a percentage of females placed with a male) and mating index (number of females delivering live litters expressed as a percentage of the females in which matings were detected) of treated groups were consistently greater than control values. A consistent dose-related increase of fertility index was observed for $F_{0}$ females; the fertility index of the $0.60 \mathrm{mg} / \mathrm{kg}$ group was significantly greater $(P<0.05)$ than controls. The male mating index (the percentage of males mating successfully with at least one female) also tended to be greater for 
TABLE 6. Body Weights ( $g$ ) of $F_{0}$ Male and Female Rats Exposed to Lewsite (Mean $\pm \mathrm{SE}$ ).

Week Control $\quad 0.10 \mathrm{mg} / \mathrm{kg} \quad 0.25 \mathrm{mg} / \mathrm{kg} \quad 0.60 \mathrm{mg} / \mathrm{kg}$

\section{MALES}

\begin{tabular}{|c|c|c|c|c|c|c|c|c|}
\hline 0 & $269.4 \pm$ & 3.5 & $268.4 \pm$ & 3.2 & $258.2 \pm$ & 7.0 & $268.1 \pm$ & 3.6 \\
\hline 1 & $322.8 \pm$ & 4.3 & $321.2 \pm$ & 4.4 & $314.7 \pm$ & 3.9 & $320.7 \pm$ & 4.4 \\
\hline 2 & $369.7 \pm$ & 4.9 & $368.1 \pm$ & 5.5 & $358.4 \pm$ & 4.5 & $365.3 \pm$ & 4.4 \\
\hline 3 & $405.5 \pm$ & 5.5 & $406.3 \pm$ & 6.6 & $396.2 \pm$ & 5.2 & $398.0 \pm$ & 5.2 \\
\hline 4 & $431.6 \pm$ & 5.7 & $437.6 \pm$ & 7.5 & $425.8 \pm$ & 5.8 & $432.6 \pm$ & .5 \\
\hline 5 & $459.6 \pm$ & 6.6 & $462.6 \pm$ & 7.5 & $452.1 \pm$ & 6.1 & $460.4 \pm$ & 6.6 \\
\hline 6 & $478.6 \pm$ & 7.1 & $487.6 \pm$ & 8.1 & $476.7 \pm$ & 6.3 & $484.8 \pm$ & 6.7 \\
\hline 7 & $500.8 \pm$ & 7.7 & $511.3 \pm$ & 9.2 & $501.0 \pm$ & 6.5 & $506.4 \pm$ & 7.1 \\
\hline 8 & $521.9 \pm$ & 7.3 & $530.7 \pm$ & 9.5 & $517.4 \pm$ & 8.0 & $523.6 \pm$ & 8.1 \\
\hline 9 & $541.3 \pm$ & 8.0 & $545.7 \pm$ & 10.0 & $535.3 \pm$ & 8.8 & $538.8 \pm$ & 7.6 \\
\hline 10 & $560.3 \pm$ & 8.3 & $564.9 \pm$ & 10.1 & $553.4 \pm$ & 8.0 & $558.1 \pm$ & 7.7 \\
\hline 11 & $572.3 \pm$ & 8.4 & $580.0 \pm$ & 10.0 & $568.4 \pm$ & 8.0 & $571.1 \pm$ & 7.8 \\
\hline 12 & $580.0 \pm$ & 8.7 & $587.0 \pm$ & 9.5 & $576.6 \pm$ & 8.0 & $582.5 \pm$ & 8.1 \\
\hline 13 & $585.6 \pm$ & 9.1 & $587.8 \pm$ & 9.1 & $579.0 \pm$ & 7.7 & $582.0 \pm$ & 8.3 \\
\hline & \multicolumn{8}{|c|}{ FEMALES } \\
\hline 0 & $182.1 \pm$ & 1.9 & $180.3 \pm$ & 2.3 & $179.0 \pm$ & 2.0 & $182.2 \pm$ & 1.9 \\
\hline 1 & $207.3 \pm$ & 2.4 & $201.6 \pm$ & 2.7 & $200.1 \pm$ & 2.3 & $208.2 \pm$ & 2.8 \\
\hline 2 & $228.0 \pm$ & 2.8 & $222.2 \pm$ & 3.2 & $218.3 \pm$ & 2.5 & $228.7 \pm$ & 3.4 \\
\hline 3 & $247.6 \pm$ & 2.8 & $241.6 \pm$ & 3.6 & $236.4 \pm$ & 2.9 & $247.1 \pm$ & 3.8 \\
\hline 4 & $261.4 \pm$ & 3.3 & $255.5=$ & 4.5 & $251.2 \pm$ & 3.4 & $265.8 \pm$ & 4.0 \\
\hline 5 & $276.8 \pm$ & 3.4 & $269.6 \pm$ & 4.9 & $261.5 \pm$ & 3.5 & $278.2 \pm$ & 3.8 \\
\hline 6 & $279.6 \pm$ & 3.4 & $273.4 \pm$ & 5.2 & $271.9 \pm$ & 3.9 & $288.8 \pm$ & 4.0 \\
\hline 7 & $295.6 \pm$ & 4.0 & $282.9 \pm$ & 5.3 & $281.1 \pm$ & 4.3 & $297.2 \pm$ & 4.5 \\
\hline 8 & $304.3 \pm$ & 4.6 & $293.1 \pm$ & 5.7 & $287.3 \pm$ & 4.4 & $306.5 \pm$ & 4.9 \\
\hline 9 & $312.7 \pm$ & 5.1 & $299.5 \pm$ & 6.2 & $294.7 \pm$ & 4.4 & $313.2 \pm$ & 5.7 \\
\hline 10 & $322.8 \pm$ & 5.2 & $308.4 \pm$ & 5.8 & $303.8 \pm$ & 4.6 & $323.7 \pm$ & 5.4 \\
\hline 11 & $329.5 \pm$ & 5.8 & $314.7 \pm$ & 6.5 & $307.9 \pm$ & 4.4 & $332.8 \pm$ & 7.0 \\
\hline 12 & $330.0=$ & 5.4 & 319.0 & 6.9 & $308.7 \pm$ & 4.9 & $334.0 \pm$ & 6.7 \\
\hline 13 & $337.4 \pm$ & 5.4 & $326.8 \pm$ & 6.8 & $315.4 \pm$ & 4.5 & $339.5 \pm$ & 6. \\
\hline
\end{tabular}


Table 7. Body Weights ( $g$ ) of $\mathrm{F}_{1}$ Male and Female Rats Exposed to Lewisite (Mean $\pm \mathrm{SE}$ ).

\begin{tabular}{lllll}
\hline Week Control & $0.10 \mathrm{mg} / \mathrm{kg}$ & $0.25 \mathrm{mg} / \mathrm{kg}$ & $0.60 \mathrm{mg} / \mathrm{kg}$
\end{tabular}

MALES

$\begin{array}{lrrrrrr}0 & 81.5 \pm 2.9 & 84.7 \pm 1.9 & 81.4 \pm 2.0 & 84.5 \pm 1.8 \\ 1 & 120.6 \pm 6.5 & 130.7 \pm 5.5 & 125.3 \pm 5.8 & 130.4 \pm 6.0 \\ 2 & 181.1 \pm 9.2 & 184.4 \pm 9.2 & 186.8 \pm 7.2 & 185.1 \pm 8.4 \\ 3 & 246.9 \pm 9.4 & 247.3 \pm 10.0 & 250.3 \pm 7.6 & 246.1 \pm 9.8 \\ 4 & 309.2 \pm 9.7 & 309.0 \pm 10.4 & 305.5 \pm 7.9 & 304.1 \pm 10.5 \\ 5 & 368.8 \pm 9.3 & 365.6 \pm 10.7 & 357.1 \pm 7.9 & 355.8 \pm 10.5 \\ 6 & 415.3 \pm 9.2 & 411.7 \pm 10.4 & 393.3 \pm 6.6 & 396.0 \pm 11.2 \\ 7 & 452.9 \pm 9.1 & 445.0 \pm 9.3 & 426.9 \pm 6.8 & 416.2 \pm 23.1 \\ 8 & 492.6 \pm 9.5 & 479.9 \pm 9.2 & 457.4 \pm 7.9 & 466.9 \pm 11.2 \\ 9 & 514.4 \pm 10.4 & 506.1 \pm 9.2 & 478.9 \pm 7.3 & 496.4 \pm 10.7 \\ 10 & 537.0 \pm 10.8 & 529.9 \pm 9.4 & 501.8 \pm 7.8 & 522.3 \pm 10.8 \\ 11 & 563.0 \pm 11.4 & 551.1 \pm 10.3 & 521.3 \pm 8.4 * & 545.3 \pm 10.9 \\ 12 & 583.6 \pm 12.1 & 571.6 \pm 11.3 & 539.4 \pm 9.1 * & 561.1 \pm 12.7 \\ 13 & 590.8 \pm 11.9 & 580.9 \pm 11.6 & 543.8 \pm 8.7 & 555.5 \pm 17.5\end{array}$

FEMALES

$\begin{array}{rrrrrrr}0 & 77.4 \pm 2.2 & 80.1 \pm 1.1 & 76.4 \pm 1.8 & 78.3 \pm 2.4 \\ 1 & 110.9 \pm & 4.8 & 116.4 \pm 3.7 & 112.3 \pm 4.4 & 116.3 \pm 4.1 \\ 2 & 151.2 \pm & 5.5 & 151.5 \pm & 5.1 & 154.3 \pm 4.5 & 151.7 \pm 4.9 \\ 3 & 185.6 \pm & 4.4 & 183.1 \pm 3.8 & 182.5 \pm 3.7 & 183.1 \pm 4.4 \\ 4 & 212.7 \pm & 3.3 & 209.3 \pm 3.9 & 206.5 \pm 4.5 & 205.7 \pm 4.7 \\ .5 & 236.1 \pm 3.9 & 232.0 \pm 4.0 & 228.5 \pm 3.7 & 227.9 \pm 4.4 \\ 6 & 256.5 \pm 4.0 & 249.0 \pm 4.5 & 243.9 \pm 4.3 & 234.9 \pm 6.4 * \\ 7 & 270.9 \pm 3.4 & 263.0 \pm 4.6 & 254.4 \pm 4.5 & 257.8 \pm 6.4 \\ 8 & 288.4 \pm 3.7 & 275.6 \pm 4.9 & 270.8 \pm 4.7 & 278.2 \pm 6.5 \\ 9 & 296.6 \pm 4.0 & 285.1 \pm 4.8 & 281.2 \pm 4.2 & 291.0 \pm 6.4 \\ 10 & 306.6 \pm 4.8 & 291.6 \pm 5.0 & 288.2 \pm 4.4 & 301.6 \pm 7.1 \\ 11 & 318.5 \pm 5.5 & 303.8 \pm 5.1 & 300.6 \pm 5.4 & 308.3 \pm 7.9 \\ 12 & 327.8 \pm 5.7 & 312.1 \pm 5.9 & 308.5 \pm 5.7 & 315.0 \pm 8.4 \\ 13 & 336.1 \pm 5.8 & 316.5 \pm 6.2 & 306.5 \pm 6.1 & 317.2 \pm 10.7\end{array}$

*Significantly different from control value by Tukey's Test (P<0.05). 

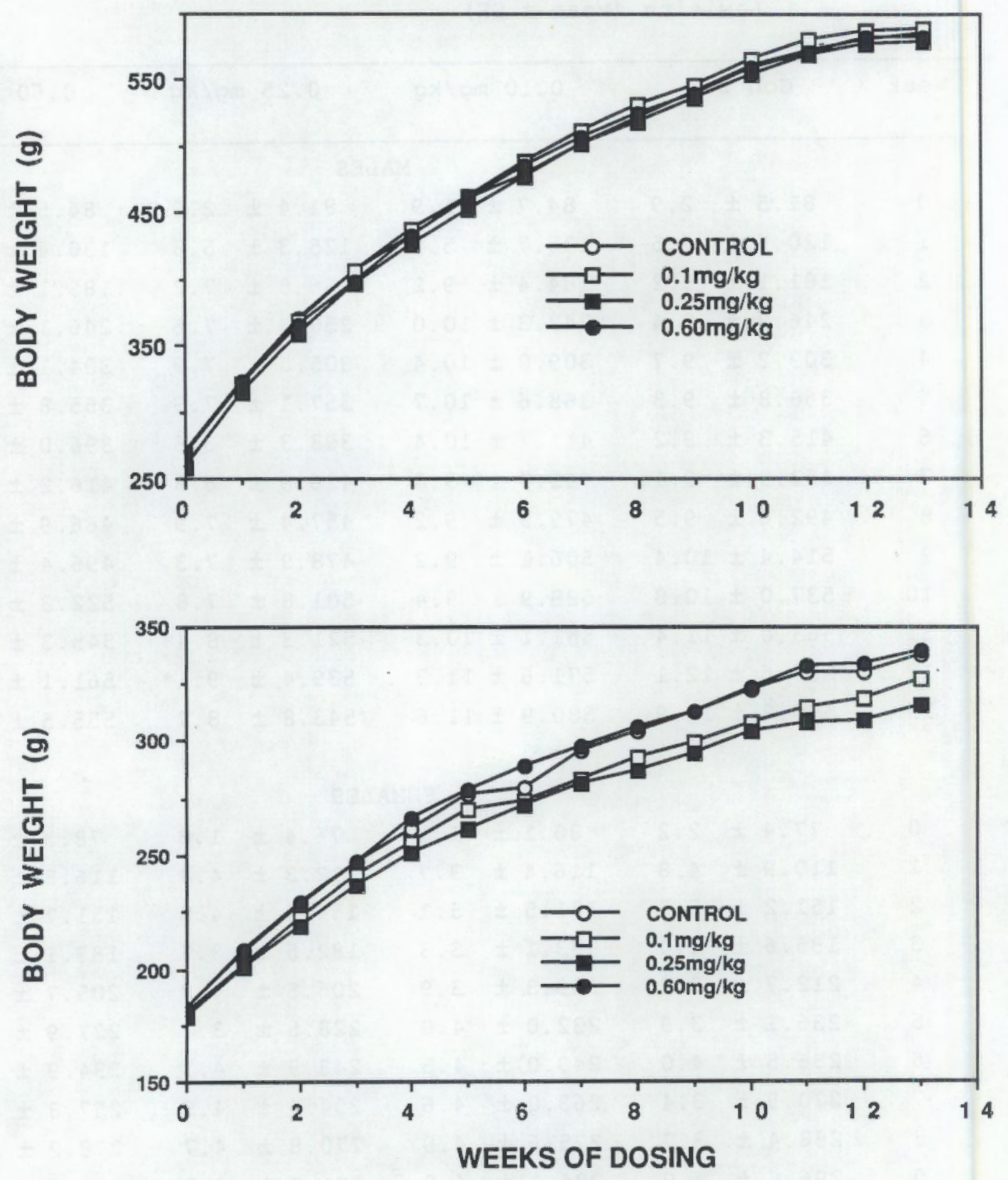

Figure 2. Body weights of Fo male and female rats gavaged with Lewisite for 13 weeks. 

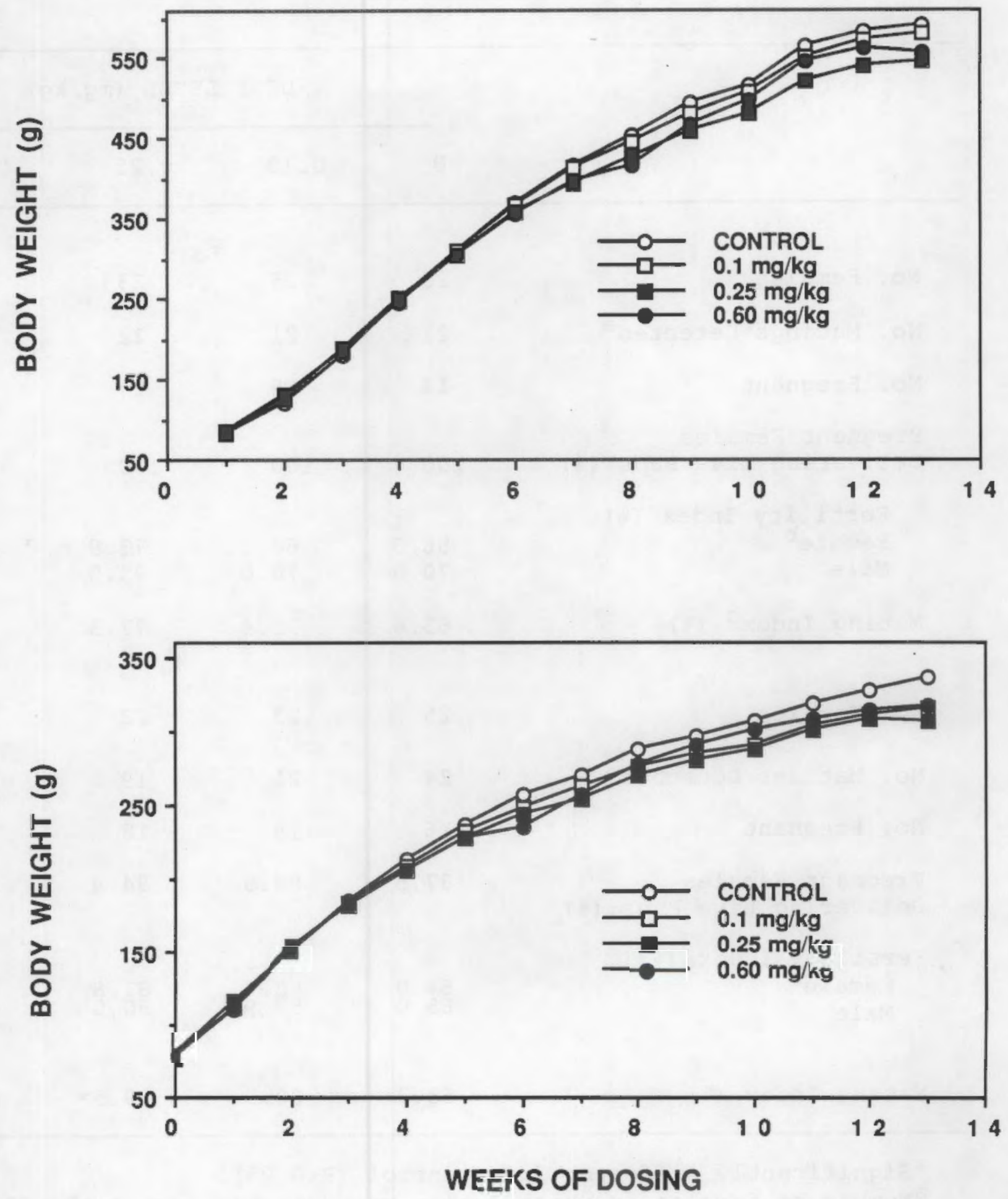

Figure 3. Body weights of $F_{1}$ male and female rats gavaged with Lewisite for 13 weeks. 
Table 8. Reproductive Performance of $F_{0}$ and $F_{1}$ Rats Exposed to Lewisite.

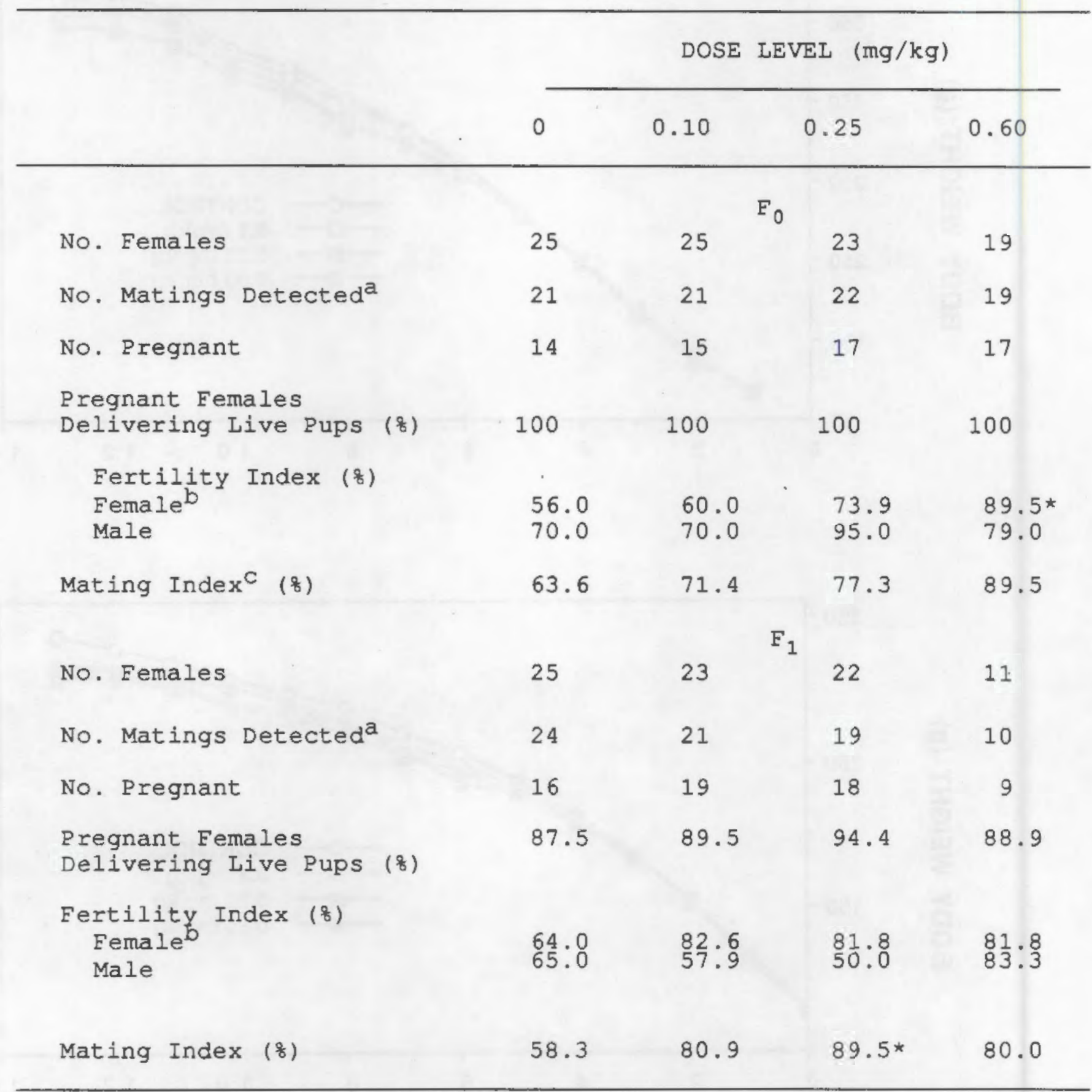

*Significantly different from control $(P<0.05)$.

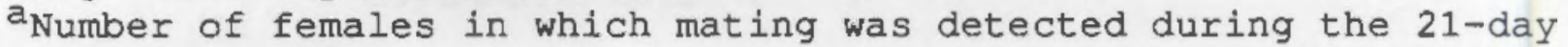
lavaging period.

${ }^{b}$ Number of females delivering a litter expressed as a percentage of females placed with a male.

The number of females delivering live litters expressed as a percentage of the females in which matings were detected. 
Lewisite treated animals than for controls, although the only statistically significant $(P<0.05)$ change occurred in $F_{1}$ males given Lewisite at a dose of $0.25 \mathrm{mg} / \mathrm{kg}$ (Table 8). The biological significance of these positive responses for Lewisite-treated animals is not clear, although the slight Lewisite-induced reduction in body weight may have contributed to improval reproductive performance.

Lewisite treatment did not result in significant changes in litter weights, sex ratio or mean live pup weights for either generation (Table 9). Likewise the number of stillbirths and abnormal pups were unaffected by Lewisite treatment. Only three abnormal pups were found upon gross examination of the litters; two were hairless pups from the same 1 itter $\left(F_{0}, 0.08 \mathrm{mg} / \mathrm{kg}\right.$ ) and the other, from the $F_{0}$ mid-dose group, had a short or stubbed tail. One $F_{0}$ control female failed to deliver her dead fetuses and uterine nidation sites were found in six $F_{1}$ females ( 2 controls, 2 low dose, 2 mid-dose and high dose).

Pup survival through weaning was unaffected by parental exposure to Lewisite. Although pup weights were generally not different among treatment groups, weights at 4 days of age were depressed for $F_{1}$ males $(0.10 \mathrm{mg} / \mathrm{kg})$ and $\mathrm{F}_{2}$ females $(0.25 \mathrm{mg} / \mathrm{kg}$ ) (Table 10$)$.

Body weights and weights of selected reproductive organs of $F_{0}$ and $F_{1}$ males and of $F_{0}$ and $F_{1}$ females surviving to the scheduled necropsy are presented in Table 11 and 12, respectively. Excluded from these results are data of animals classified as early deaths and of non-gravid females not continued in the reproductive phases of the study. Terminal body weights were generally not adversely influenced by Lewisite treatment, except for a significant decrease $(P<0.05)$ for $F_{0}$ females and $F_{1}$ males exposed to 0.25 $\mathrm{mg} / \mathrm{kg}$ Lewisite. Neither absolute nor relative reproductive organ weights of either generation were affected by Lewisite exposure.

Necropsy and Histological Observation

A complete necropsy was performed on all parental animals of the $F_{0}$ and $F_{1}$ generation. Gross lesions observed at necropsy or tissue trimming were recorded on the Individual Animal Necropsy Record for each animal. 
Table 9. Birth Measurements of $F_{0}$ and $F_{1}$ Exposed to Lewsite During Pregnancy (Mean $\pm \mathrm{SE}$ ).

\begin{tabular}{|c|c|c|c|c|}
\hline & & DOSE LEVELS & $(\mathrm{mg} / \mathrm{kg})$ & \\
\hline & 0 & 0.10 & 0.25 & 0.60 \\
\hline & \multicolumn{4}{|c|}{$F_{0}$} \\
\hline No. Litters & 13 & 14 & 16 & 13 \\
\hline Litter wt. (g) & $80.1 \pm 6.5$ & $94.9 \pm 3.6$ & $81.4 \pm 7.5$ & $76.7 \pm 8.52$ \\
\hline $\begin{array}{l}\text { Sex Ratio } \\
\text { (Fraction of Males) }\end{array}$ & $0.51 \pm 0.05$ & $0.45 \pm 0.03$ & $0.57 \pm 0.05$ & $0.50 \pm 0.06$ \\
\hline $\begin{array}{l}\text { Live Pup wt. } \\
\text { (g/litter) }\end{array}$ & $6.73 \pm 0.16$ & $6.55 \pm 0.14$ & $6.52 \pm 0.32$ & $6.81 \pm 0.32$ \\
\hline No. Iive Pups & $11.7 \pm 0.96$ & $14.5 \pm 0.65$ & $11.8 \pm 1.11$ & $11.1 \pm 1.28$ \\
\hline $\begin{array}{l}\text { No. Stillbirths } \\
\text { per Litter }\end{array}$ & $0.23 \pm 0.12$ & $0.07 \pm 0.07$ & $0.81 \pm 0.43$ & $0.46 \pm 0.39$ \\
\hline No. Abnormal Pups & 0 & 2 & 1 & 0 \\
\hline $\begin{array}{l}\text { Pup Survival Index( } 8) \\
0 \text { to } 4 \text {-day }\end{array}$ & 100 & 100 & $97.2 \pm 1.9$ & $97.8 \pm 2.9$ \\
\hline 4 to $21-$ day ${ }^{\star}$ & 100 & $99.1 \pm 0.89$ & 100 & 100 \\
\hline & & $\mathrm{F}_{1}$ & & \\
\hline No. Litters & 13 & 17 & 15 & 5 \\
\hline Litter wt. (g) & $89.3 \pm 2.9$ & $80.2 \pm 6.3$ & $91.4 \pm 4.4$ & $102.0 \pm 4$ \\
\hline $\begin{array}{l}\text { Sex Ratio } \\
\text { (Fraction of males) }\end{array}$ & $0.53 \pm 0.05$ & $0.49 \pm 0.03$ & $0.48 \pm 0.03$ & $0.58 \pm 0.08$ \\
\hline $\begin{array}{l}\text { Live Pup wt. } \\
\text { (g/litter) }\end{array}$ & $6.48 \pm 0.15$ & $6.57 \pm 0.17$ & $6.25 \pm 0.13$ & $6.80 \pm 0.13$ \\
\hline $\begin{array}{l}\text { No. Live Pups } \\
\text { per Litter }\end{array}$ & $13.5 \pm 0.53$ & $12.1 \pm 0.99$ & $14.4 \pm 0.63$ & $15.0 \pm 0.63$ \\
\hline $\begin{array}{l}\text { No. Stillbirths } \\
\text { per Litter }\end{array}$ & $0.38 \pm 0.27$ & $0.41 \pm 0.21$ & $0.20 \pm 0.14$ & 0 \\
\hline No. Abnormal Pups & 0 & 0 & 0 & 0 \\
\hline $\begin{array}{l}\text { Pup Survival Index( }(8) \\
0 \text { to } 4 \text {-day } \\
4 \text { to } 21-\text { day }\end{array}$ & $\begin{array}{l}100 \\
99.0 \pm 0.6\end{array}$ & $\begin{array}{l}97.1 \\
100\end{array}$ & $\begin{array}{l}98.2 \\
93.3 \pm 6.7\end{array}$ & $\begin{array}{l}98.7 \\
100\end{array}$ \\
\hline
\end{tabular}


Table 10. Body weight $(g)$ of $F_{1}$ and $F_{2}$ Male and Female Pups During Nursing (Mean tSE).

\section{DOSE LEVEL (mg/kg)}

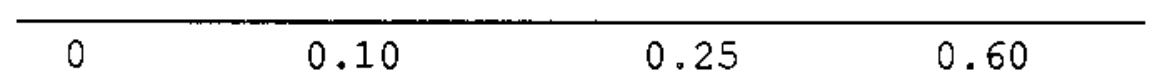

$F_{1}$

MALES

Day 4

$12.3 \pm 0.21$

$11.3 \pm 0.24$ *

$12.2 \pm 0.23$

$12 \cdot 3 \pm 0.30$

Day 14

$38.4 \pm 0.41$

$38.5 \pm 0.70$

$39.0 \pm 0.33$

$38.4 \pm 0.66$

Day 21

$65.0 \pm 1.04$

$66.4 \pm 1.16$

$67.6 \pm 0.58$

$66.8 \pm 0.93$

EEMALES

Day 4

$11.4 \pm 0.21$

$10.6 \pm 0.22$

$12.0 \pm 0.22$

$11.2 \pm 0.32$

Day 14

$36.8 \pm 0.47$

$37.6 \pm 0.52$

$37.8 \pm 0.36$

$37.3 \pm 0.71$

Day 21

$62.2 \pm 0.86$

$63.6 \pm 0.81$

$65.5 \pm 0.54$ *

$64.0 \pm 1.07$

$\mathrm{F}_{2}$

MALES

Day 4

$11.5 \pm 0.21$

$11.5 \pm 0.23$

$10.5 \pm 0.25$

$11.6 \pm 0.24$

Day 14

$37.8 \pm 0.67$

$37.6 \pm 0.63$

$36.8 \pm 0.49$

$38.4 \pm 0.75$

Day 21

$63.6 \pm 0.79$

$63.9 \pm 0.91$

$62.1 \pm 0.85$

$63.8 \pm 0.72$

FEMALES

$\begin{array}{lllll}\text { Day } 4 & 11.2 \pm 0.22 & 11.4 \pm 0.22 & 10.0 \pm 0.20 * & 10.9 \pm 0.23 \\ \text { Day } 14 & 37.2 \pm 0.58 & 37.4 \pm 0.53 & 35.8 \pm 0.47 & 36.9 \pm 1.05 \\ \text { Day } 21 & 61.9 \pm 0.77 & 62.5 \pm 0.79 & 59.4 \pm 0.78 & 61.6 \pm 1.08\end{array}$

*Significantly different from control value by Tukey's Test $(\mathrm{P}<0.05)$. 
Table 11. Body and Reproductive Organ Weights at Scheduled Necropsy of $F_{0}$ and $F_{1}$ Male Rats Exposed to Lewisite (Mean $\pm S E$ ).

\begin{tabular}{|c|c|c|c|c|c|c|c|c|}
\hline \multirow{2}{*}{$\begin{array}{l}\text { Lewisite } \\
\mathrm{mg} / \mathrm{kg} / \mathrm{day}\end{array}$} & \multirow[t]{2}{*}{$\mathrm{N}$} & \multirow{2}{*}{$\begin{array}{c}\text { Body } \\
\text { weight } \\
\text { g }\end{array}$} & \multicolumn{2}{|c|}{$\begin{array}{l}\text { Epididymis } \\
\text { Weight }\end{array}$} & \multicolumn{2}{|c|}{$\begin{array}{l}\text { Prostate } \\
\text { Weight }\end{array}$} & \multicolumn{2}{|c|}{$\begin{array}{l}\text { Testes } \\
\text { Weight }\end{array}$} \\
\hline & & & $\mathrm{g}$ & $\mathrm{mg} / 100 \mathrm{~g}$ & $\mathrm{mg}$ & $\mathrm{mg} / 100 \mathrm{~g}$ & $\mathrm{~g}$ & $\mathrm{mg} / 100 \mathrm{~g}$ \\
\hline \multicolumn{9}{|c|}{$F_{0}$} \\
\hline 0 & 20 & $\begin{array}{r}624.5 \\
\pm 11.2\end{array}$ & $\begin{array}{c}1.29 \\
\pm 0.034\end{array}$ & $\begin{array}{c}207 \star \star \\
\pm 6\end{array}$ & $\begin{array}{l}561 \star \star \\
\pm 34\end{array}$ & $\begin{array}{r}91 \\
\pm 6\end{array}$ & $\begin{array}{r}3.57 \\
\pm 0.11\end{array}$ & $\begin{array}{l}572 \\
\pm 18\end{array}$ \\
\hline 0.10 & 20 & $\begin{array}{r}620.9 \\
\pm 10.5\end{array}$ & $\begin{aligned} & 1.29 \\
& \pm 0.023\end{aligned}$ & $\begin{array}{r}209 \\
\pm 5\end{array}$ & $\begin{array}{l}600 \\
\pm 34\end{array}$ & $\begin{array}{l}97 \\
\pm 5\end{array}$ & $\begin{array}{r}3.56 \\
\pm 0.04\end{array}$ & $\begin{array}{l}576 \\
\pm 11\end{array}$ \\
\hline 0.25 & 20 & $\begin{array}{l}610.8 \\
\pm 10.2\end{array}$ & $\begin{aligned} & 1.26 \\
& \pm 0.030\end{aligned}$ & $\begin{array}{r}208 \\
\pm 6\end{array}$ & $\begin{array}{l}528 \\
\pm 33\end{array}$ & $\begin{array}{l}87 \\
\pm 6\end{array}$ & $\begin{array}{r}3.62 \\
\pm 0.06\end{array}$ & $\begin{array}{l}595 \\
\pm 12\end{array}$ \\
\hline 0.60 & 16 & $\begin{array}{r}619.8 \\
\pm 10.6\end{array}$ & $\begin{array}{c}1.28 \\
\pm 0.031\end{array}$ & $\begin{array}{r}206 \\
\pm 6\end{array}$ & $\begin{array}{r}532 \\
\pm 38\end{array}$ & $\begin{array}{l}86 \\
\pm 6\end{array}$ & $\begin{array}{r}3.51 \\
\pm 0.06\end{array}$ & $\begin{array}{c}569 \\
\pm 12\end{array}$ \\
\hline \multicolumn{9}{|c|}{$F_{1}$} \\
\hline 0 & 20 & $\begin{array}{r}626.2 \\
\pm 16.8\end{array}$ & $\begin{array}{c}1.35 \\
\pm 0.018\end{array}$ & $\begin{array}{r}219 \\
\pm 6\end{array}$ & $\begin{array}{r}695 \\
\pm 37\end{array}$ & $\begin{array}{r}112 \\
\pm 6\end{array}$ & $\begin{array}{c}3.73 \\
\pm 0.067\end{array}$ & $\begin{array}{l}603 \\
\pm 18\end{array}$ \\
\hline 0.10 & 19 & $\begin{array}{r}606.9 \\
\pm 14.5\end{array}$ & $\begin{array}{c}1.38 \\
\pm 0.021\end{array}$ & $\begin{array}{r}230 \\
\pm 5\end{array}$ & $\begin{array}{r}634 \\
\pm 37\end{array}$ & $\begin{array}{r}105 \\
\pm 6\end{array}$ & $\begin{array}{r}3.68 \\
\pm 0.059\end{array}$ & $\begin{array}{r}612 \\
\pm 14\end{array}$ \\
\hline 0.25 & 18 & $\begin{array}{l}564.5^{\star} \\
\pm 9.4\end{array}$ & $\begin{array}{r}1.29 \\
\pm 0.037\end{array}$ & $\begin{array}{r}229 \\
\pm 7\end{array}$ & $\begin{array}{r}614 \\
\pm 33\end{array}$ & $\begin{array}{r}109 \\
\pm 6\end{array}$ & $\begin{array}{r}3.63 \\
\pm 0.059\end{array}$ & $\begin{array}{l}647 \\
\pm 17\end{array}$ \\
\hline 0.60 & 14 & $\begin{array}{l}622.7 \\
\pm 18.0\end{array}$ & $\begin{array}{l}1.29 \\
\pm 0.028\end{array}$ & $\begin{array}{r}210 \\
\pm 8\end{array}$ & $\begin{array}{r}658 \\
\pm 33\end{array}$ & $\begin{array}{r}107 \\
\pm 6\end{array}$ & $\begin{array}{r}3.65 \\
\pm 0.081\end{array}$ & $\begin{array}{r}591 \\
\pm 18\end{array}$ \\
\hline
\end{tabular}

*Significantly different from control value by Tukey's Test (P<0.05). $\star \star N=19$ 
Table 12. Body and Reproductive Organ Weights at Scheduled Necropsy of $F_{0}$ and $F_{1}$ Female Rats Exposed to Lewisite (Mean $\pm \mathrm{SE}$ ).

\begin{tabular}{|c|c|c|c|c|c|c|}
\hline \multirow{2}{*}{$\begin{array}{l}\text { Lewisite } \\
\text { mg/kg/day }\end{array}$} & \multirow[t]{2}{*}{$\mathrm{N}$} & \multirow{2}{*}{$\begin{array}{c}\text { Body } \\
\text { Weight } \\
g\end{array}$} & \multicolumn{2}{|c|}{$\begin{array}{l}\text { Uterus } \\
\text { Weight }\end{array}$} & \multicolumn{2}{|c|}{$\begin{array}{l}\text { Ovary } \\
\text { Weight }\end{array}$} \\
\hline & & & $\mathrm{mg}$ & $\mathrm{mg} / 100 \mathrm{~g}$ & $\mathrm{mg}$ & $\mathrm{mg} / 100 \mathrm{~g}$ \\
\hline \multicolumn{7}{|c|}{$\mathrm{F}_{0}$} \\
\hline 0 & 14 & $\begin{array}{r}360.4 \\
\pm 7.1\end{array}$ & $\begin{array}{l}541 \\
\pm 65\end{array}$ & $\begin{array}{l}151 \\
\pm 18\end{array}$ & $\begin{array}{r}103 \\
\pm 6\end{array}$ & $\begin{array}{l}29 \\
\pm 2\end{array}$ \\
\hline 0.10 & 13 & $\begin{array}{r}353.8 \\
\pm 6.5\end{array}$ & $\begin{array}{r}587 \\
\pm 61\end{array}$ & $\begin{array}{l}165 \\
\pm 17\end{array}$ & $\begin{array}{l}90 \\
\pm 4\end{array}$ & $\begin{array}{l}25 \\
\pm 1\end{array}$ \\
\hline 0.25 & 16 & $\begin{array}{c}338.1^{\star} \\
\pm 5.3\end{array}$ & $\begin{array}{l}562 \\
\pm 59\end{array}$ & $\begin{array}{l}168 \\
\pm 18\end{array}$ & $\begin{array}{r}99 \\
\pm 5\end{array}$ & $\begin{array}{l}29 \\
\pm 1\end{array}$ \\
\hline 0.60 & 13 & $\begin{array}{r}367.3 \\
\pm 7.8\end{array}$ & $\begin{array}{l}488^{\star *} \\
\pm 49\end{array}$ & $\begin{array}{l}133 \\
\pm 11\end{array}$ & $\begin{array}{l}93 \\
\pm 6\end{array}$ & $\begin{array}{l}25 \\
\pm 1\end{array}$ \\
\hline & \multicolumn{6}{|c|}{$F_{1}$} \\
\hline 0 & 13 & $\begin{array}{r}339.7 \\
\pm 7.2\end{array}$ & $\begin{array}{l}552 \\
\pm 32\end{array}$ & $\begin{array}{r}163 \\
\pm 9\end{array}$ & $\begin{array}{r}116 \\
\pm 5\end{array}$ & $\begin{array}{l}34 \\
\pm 2\end{array}$ \\
\hline 0.10 & 17 & $\begin{array}{r}322.5 \\
\pm 5.4\end{array}$ & $\begin{array}{l}567 \\
\pm 35\end{array}$ & $\begin{array}{l}176 \\
\pm 10\end{array}$ & $\begin{array}{r}113 \\
\pm 8\end{array}$ & $\begin{array}{l}35 \\
\pm 2\end{array}$ \\
\hline 0.25 & 14 & $\begin{array}{r}321.1 \\
\pm 5.3\end{array}$ & $\begin{array}{l}584 \\
\pm 56\end{array}$ & $\begin{array}{l}182 \\
\pm 17\end{array}$ & $\begin{array}{r}125 \\
\pm 6\end{array}$ & $\begin{array}{l}39 \\
\pm 2\end{array}$ \\
\hline 0.60 & 3 & $\begin{array}{r}347.5 \\
\pm 5.8\end{array}$ & $\begin{array}{r}610 \\
\pm 34\end{array}$ & $\begin{array}{l}176 \\
\pm 11\end{array}$ & $\begin{array}{l}132 \\
\pm 11\end{array}$ & $\begin{array}{r}38 \\
\pm 4\end{array}$ \\
\hline
\end{tabular}


There were no gross lesions directly attributable to the intragastric administration of Lewisite. In the respiratory system of rats that died before scheduled sacrifice, a variety of changes were observed at necropsy. Most of these consisted of fluid accumulation in the thoracic cavity, mottled discoloration of lungs, and small pulmonary foci that were either red or light gray in several animals. In some cases these were probably agonal or early autolytic changes that were not related to administration of the test material. In other animals, the test material entered the respiratory system or thoracic cavity either because of an accident in dosing, or by reflux and aspiration of material administered by gavage. In these cases, the presence of test material in the respiratory system caused a lesion. The incidence and nature of all respiratory changes have been documented in histopathological data.

A number of other gross lesions were observed in control and Lewisitetreated rats in this study. Either these changes did not correlate with treatment and were not considered significant histologically, or there were no corresponding noteworthy microscopic changes.

Protocol-required tissues for histologic examination were ovaries, uterus, vagina, testes, seminal vesicles, prostate, epididymis, and target organs of all control and high dose $(0.60 \mathrm{mg} / \mathrm{kg}) F_{0}$ and $F_{1}$ animals selected for mating including those that failed to mate. Target organs identified in the 0.60 $\mathrm{mg} / \mathrm{kg}$ group were to be examined in lower dose groups as were tissues having gross lesions.

Histopathologic observations were entered directly into the xybion Path/Tox data management system. The intent was to evaluate microscopicaliy all protocol required tissues. This objective was not achieved since tissues from seven $F_{0}$ females in the $0.60 \mathrm{mg} / \mathrm{kg}$ group and eight $F_{0}$ control females were improperly fixed and unavailable for histologic examination. In addition, one or more tissues from about 20 animals were missing or the available tissues from several animals were unsuitable for evaluation because of autolysis. Therefore, the number of tissues per group examined microscopically was not always the same as the number of animals in the group. Tissues were examined from a total of 179 animals in this study as shown in Table 13.

There were no microscopic lesions attributable to intragastric administration of Lewisite in any of the tissues for which histopathologic examination was required. A variety of non-neoplastic lesions in numerous 
Table 13. Histological Examination of $F_{0}$ and $F_{1}$ rat tissues.

\begin{tabular}{|c|c|c|c|c|c|}
\hline $\begin{array}{l}\text { Experimental } \\
\text { Group }\end{array}$ & $\begin{array}{l}\text { Number } \\
\text { In Group }\end{array}$ & $\begin{array}{l}\text { Early } \\
\text { Death }\end{array}$ & $\begin{array}{l}\text { Moribund } \\
\text { Sacrifice }\end{array}$ & $\begin{array}{l}\text { Terminal } \\
\text { Sacrifice }\end{array}$ & $\begin{array}{l}\text { Not } \\
\text { Examined }\end{array}$ \\
\hline & \multicolumn{5}{|c|}{$F_{0}$} \\
\hline Control females & 25 & 1 & 0 & 17 & 7 \\
\hline Control males & 20 & 0 & 0 & 20 & 0 \\
\hline $0.60 \mathrm{mg} / \mathrm{kg}$ females & 25 & 11 & 0 & 7 & 8 \\
\hline $0.60 \mathrm{mg} / \mathrm{kg}$ males & 20 & 4 & 0 & 16 & 0 \\
\hline $0.25 \mathrm{mg} / \mathrm{kg}$ females & 25 & 4 & 0 & 0 & $\mathrm{NA}^{\mathrm{a}}$ \\
\hline $0.25 \mathrm{mg} / \mathrm{kg}$ males & 20 & 0 & 0 & 0 & NA \\
\hline $0.10 \mathrm{mg} / \mathrm{kg}$ females & 25 & 0 & 0 & 0 & NA \\
\hline \multirow{2}{*}{$0.10 \mathrm{mg} / \mathrm{kg}$ males } & 20 & 0 & 0 & 0 & NA \\
\hline & \multicolumn{5}{|c|}{$F_{1}$} \\
\hline Control females & 25 & 0 & 0 & 25 & 0 \\
\hline Control males & 20 & 0 & 0 & 20 & 0 \\
\hline $0.60 \mathrm{mg} / \mathrm{kg}$ females & 25 & 18 & 1 & 6 & 0 \\
\hline $0.60 \mathrm{mg} / \mathrm{kg}$ males & 20 & 6 & 0 & 14 & 0 \\
\hline $0.25 \mathrm{mg} / \mathrm{kg}$ females & 25 & 5 & 0 & 0 & NA \\
\hline $0.25 \mathrm{mg} / \mathrm{kg}$ males & 20 & 2 & 0 & 0 & NA \\
\hline $0.10 \mathrm{mg} / \mathrm{kg}$ females & 25 & 2 & 0 & 0 & NA \\
\hline $0.10 \mathrm{mg} / \mathrm{kg}$ males & 20 & 1 & 0 & 0 & NA \\
\hline
\end{tabular}

*No histology examination due to improper tissue fixation.

$\mathrm{a}_{\text {Not }}$ applicable; no target organs were identified. 
organs and tissues, including organs of the reproductive tract, were observed in both control and treated rats. The incidence of these changes was low and not related to experimental treatment with Lewisite. Non-neoplastic changes in the female reproductive tract were mainly associated with pregnancy or parturition. The only histologic lesions in the male reproductive organs were mild changes frequently encountered in rats of this age including mononuclear inflammatory cell infiltration in the prostate in several control and Lewisitetreated animals in both generations, and mild testicular degeneration and oligospermia in the epididymis of one $F_{0}$ control male.

Numerous microscopic changes were observed in the lungs of Lewisitetreated rats in both the $F_{0}$ and $F_{1}$ generations. Since the protocol did not require histopathological examination of the lung unless it had a gross lesion, not all lungs were examined microscopically. Pulmonary lesions included edema, hemorrhage, acute inflammation in both airways and alveoli, subacute inflammation of the pleura and mediastinal tissues, and the presence of foreign material. These lesions were limited to animals treated with Lewisite and all affected animals died prior to scheduled sacrifice. In many instances the pulmonary lesions were severe enough to be considered the cause of death. The lung lesions observed in this study were probably caused by the accidental deposition or reflux of test material into the pharynx and subsequent aspiration of this material into the trachea and lungs. In one $F_{1}$ generation male and two $F_{1}$ fenales, there was apparent accidental perforation of the esophagus by the gavage tube and deposition of test material into the mediastinum.

Other microscopic lesions observed in this study were considered incidental findings unrelated to administration of Lewisite and of no consequence in interpretation of results. 


\section{DISCUSSION}

Results of the present study indicate that exposure, via intragastric intubation, to $0.10,0.25$ and $0.60 \mathrm{mg} / \mathrm{kg}$ Lewisite over two generations did not result in significant alterations in the reproductive performance or fertility of the rat. Likewise, no adverse effects to offspring were attributed to Lewisite exposure. Although similar long-term studies have not been conducted, these findings are consistent with those of a short-term teratology study in which no evidence of a teratogenic response was found in rats given up to 1.5 $\mathrm{mg} / \mathrm{kg}$ Lewisite (Hackett et a?., 1987.).

The Lewisite dose which may be received by the fetus under these dosing conditions is not clearly known nor can it be evaluated with the limited data available. Degregation of Lewisite is known to occur in aqueous solution, but studies of Lewisite absorption from the gastrointestinal tract or skin and its subsequent metabolism have not been conducted. No data exist regarding the placental transfer of Lewisite. Thus it cannot be positively stated that Lewisite has no adverse reproductive effect until it can be determined whether or not Lewisite is actually transported to the developing fetus.

A majority of the early deaths in this study could be attributed to lesions of the respiratory tract, probably the result of accidental deposition or induced reflux of the test material into the pharynx and subsequent aspiration of the Lewisite into the larynx, trachea, lungs and nasal cavity. These animals did not show signs of Lewisite toxicity, even after long-term exposure, until 2 or 3 days prior to death, suggesting that a single event may have been responsible for the mortality. Evidence of respiratory tract lesions was not found when sulfur mustard, another strong vesicant, was administered at concentrations sufficiently great to cause weight loss and to induce forestomach lesions (Sasser et al., 1989b). Lewisite exposure, unlike the action of sulfur mustard in which pain may be delayed, is characterized by immediate onset of pain; gastrointestinal and respiratory tissues are especially known to be sensitive (Gates et al., 1946). Indeed, Lewisite may have been irritating enough to evoke an immediate attempt by the rat to reject the material causing more accidental dosing trauma or actual aspiration of Lewisite into the respiratory tract than in the case of sulfur mustard. The high mortality 
caused by the sensitivity of the respiratory tract prevented the collection of reproduction data at greater doses.

other than the unique respiratory tract response, a slight reduction in growth was the only maternal effect observed. This response appeared to be stronger for the 0.25 than the $0.60 \mathrm{mg} / \mathrm{kg}$ group, but the low number of surviving animals in the $0.60 \mathrm{mg} / \mathrm{kg}$ group may have skewed the results.

Daily intragastric administration of $0.60 \mathrm{mg} / \mathrm{kg}$ of Lewisite to parental rats in the $F_{0}$ and $F_{1}$ generations of this two-generation reproductive study caused no gross or microscopic lesions in testes, epididymis, prostate, seminal vesicles, ovaries, uterus, or vagina. No target organ was identified by gross examination of all organs at necropsy or by histologic examination of protocolrequired tissues. In cases in which the test material gained access to the respiration system by either an accident in dosing or by reflux and aspiration, severe inflammation of lung resulted which usually caused death of the affected animal.

In sumary, intragastric administration of Lewisite at levels of 0.10 , 0.25 and $0.60 \mathrm{mg} / \mathrm{kg} /$ day had no adverse effect on reproductive performance, fertility or reproductive organs of male and female rats through two consecutive generations. The No-0bservable Effect-Level for reproductive effects in this study was greater than $0.60 \mathrm{mg} / \mathrm{kg}$, however, Lewisite was highly toxic and it is doubtful that greater doses could be studied by the intragastric route of exposure because of the sensitivity of the upper respiratory tract and the resulting high maternal mortality. 


\section{LITERATURE CITED}

Auerbach, C. and J.M. Robson. 1947. Tests of chemical substances for mutagenic action. Proc. Royal Soc. of Edinburgh 62B: 284-291.

Cameron, G.R., H.M. Carleton and R.H.D. Short. 1946. Pathological changes induced by Lewisite and Allied Compounds. J. Pathol. Bacteriol. 58, 411-422.

Cassarett, L.J. and J. Doull. 1986. Toxicology. The Basic Science of Poisons, 3rd Ed., MacMillan Publishers, New York, NY.

Dixon, W.J. 1983. BMDP statistical software, University of California Press, Berkley, CA.

Gates, M., J.W. Williams and J. A. Zapp. 1946. Aresenicals. Chemical Warfare Agents and Related Chemical Problems, Summary Technical Report of Division 9, National Defense Research Comittee, Vol. 1, Parts I and II, PP. 83-114. Washington, D.C.

Hackett, P.L., L.B. Sasser, R.L. Rommereim, J.A. Cushing, R.L. Buschbom and D.R. Kalkwarf. 1987. Teratology studies on Lewisite and sulfur mustard agents: Effects of Lewisite in rats and rabbits. AD A198423. U.S. Army Medical Research and Development Command, Fort Detrick, Frederick, MD.

Inns, R.H., J.E. Bright and T.C. Marrs. 1988. Comparative acute systemic toxicity of sodium arsenite and dichloro(2-chlorovinyl)arsine in rabbits. Toxicology 51: 213-222.

Jostes, R.F. Jr., R.J. Rausch and L.B. Sasser. 1989. Toxicology studies of Lewisite and sulfur mustard: Genetic toxicity of sulfur mustard (HD) in Chinese hamster ovary cells. U.S. Army Medical Research and Development Command, Ft. Detrick, Frederick, MD.

Krause, H. and E.I. Grussendorf. 1978. Syntony of Bowen's disease and Lewisite scar. Hautarzt 29: 490-493.

Leonard, A. and R.R. Lauwerys. 1980. Carcinogenicity, teratogenicity and mutagenicity of arsenic. Mutat. Res. 75: 49-62.

Loveless, A. 1951. Qualitative aspects of the chemistry and biology of radiomimetic (mutagenic) substances. Nature 167: 338-342.

Mohler, H. and J. Sorge. 1939. Chemical warfare materials. XII. Light absorption by nose and throat, lung and skin poisons in ultraviolet of short wave length. Helv. Chim. Acta 22: 235-239.

National Academy of Science. 1977. Medical and Biologic Effects of Environmental Pollutants, Arsenic. Washington, D.C.

Rewick, R.T., M.L. Schumacher and D. L. Haynes. 1986. The uv absorption spectra of chemical agents and stimulants. Appl. Spectroscopy $\underline{40}: 152-156$. 
Rosenblatt, D.H., T.A. Miller, J.C. Dacre, I. Muul, and D.R. Cogley (eds.). 1975. Problem definition of potential environmental pollutants. II. Physical, chemical, toxicological and biological properties of 16 substances. In: U.S. Army Medical Bioengineering Research and Development Technical Report 7509. AD A03H28. Fort Detrick, Frederick, MD.

SAS Institute, Inc. 1985. SAS User's Guide: Statistics Version, 5th Edition. Cary, NC: SAS Institute, Inc., 1985.

Sasser, L.B., J.A. Cushing, D.R. Kalkwarf and R.L. Buschbom. 1989 . Toxicology studies on lewisite and sulfur mustard: Subchronic toxicity of Lewisite in rats. Draft Report. U.S. Army Medical Research and Development Command, Fort Detrick, MD.

Sasser, L.B., J.A. Cushing, D.R. Kalkwarf and R.L. Miller. 1989b. Toxicology studies on Lewisite and sulfur mustard: Subchronic toxicity of sulfur mustard in rats. Draft Report. U.S. Army Medical Research and Development Command, Fort Detrick, MD.

Stewart, D.L., E.J. Sass, L.K. Fritz and L.B. Sasser. 1989. Toxicology studies on Lewisite and sulfur mustard agents: Mutagenicity study of sulfur mustard in the Salmonella histidine reversion test. Draft Report. U.S. Army Medical Research and Development Command, Ft. Detrick, Frederick, MD.

Sweet, D.V. 1987. Registry of Toxic Effects of Chemical Substances, Vol. 5, p. 1968. U.S. Government Printing Office, Washington, D.C.

Tukey, J.W. 1953. The problem of multiple comparisons. Princeton University, 3996 pp.

Wada, S., Y. Nishimoto, M. Miyanishi, S. Kambe, and R.W. Miller. 1968. Mustard gas as a cause of respiratory neoplasia in man. The Lancet 7753: 11611163.

Yamakido, M. and T. Shigenobu. 1985. The causes of death in the retired workers of Okuno-Jima poison gas factory. Jpn. J. Med. 34: 311-322.

Zerbe, G.0. 1979. Randomization analysis of completely randomized design extended to growth and response curves. J. Am. Statistical Assoc. 79: 215221 . 


\section{STUDY DATES}

Animals arrival

Health evaluation

Begin exposure of Fo generation

Begin mating fo generation

Begin birthing of $F_{1}$ generation

Begin necropsy of $F_{0}$ excess females

Weaning $F_{1}$ offspring

Begin necropsy of $F_{0}$ females

Begin dosing of $F_{1}$ generation

Begin birthing of $F 2$ generation

Begin necropsy of $F_{1}$ males and excess females

Begin sacrifice of $F_{2}$ generation

Begin necropsy of $F_{1}$ females
$02 / 03 / 87$

$02 / 20 / 87$

$02 / 20 / 87$

$05 / 25 / 87$

$06 / 17 / 87$

$06 / 15 / 87$

$07 / 08 / 87$

$07 / 09 / 87$

$07 / 10 / 87$

$11 / 03 / 87$

$11 / 11 / 87$

$11 / 24 / 87$

$12 / 10 / 87$

Data are property of U.S. Army and will be archived under the Army's direction at approved facilities. 
Function

Principal Investigators

Facility Manager

Solution Preparation and Analysis

Animal Exposures and Evaluation

Pathologist

Necropsy Evaluation

Health Evaluation

Animal Care Center

Statistical Analyses
Name

L.B. Sasser

M.T. Karagianes

D.R. Kalkwarf

C.W. Lindenmeier

L.B. Sasser

C. Veverka, Jr.

J.A. Cushing

C.W. Lindenmeier

L.B. Sasser

D.W. Shea

R.C. Zangar

R.A. Miller

P.W. Mellick

S.M. Baze

J.P. Bramson

B.L. Champion

J.A. Cushing

C.W. Lindenmeier

V.L. Madden

J. Merk ley

M. Orgill

S.A. Quinn

D.W. Shea

L.G. Smith

S.A. Stephan

K.F. Tarr

S.E. Rowe

E.L. Wierman

R.F. Buschbom

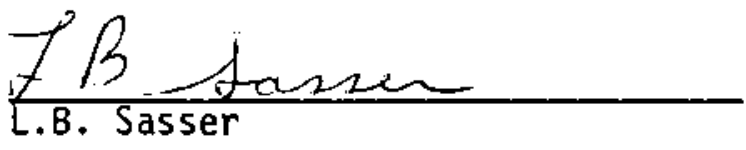

$\frac{7 \cdot 31-89}{\text { Date }}$ 
Two-Generation Reproductive Study of Lewisite in Rats

\section{Quality Assurance Statement}

Listed below are the phases and/or procedures included in the study described in this report which were reviewed by the Quality Assurance Unit during the period, 1/1/87-1/188, or specifically for this study and the dates the reviews were performed and findings reported to management. (Findings were reported to the study director or his designee at the time of the review.)

Phase/Procedure Reviewed

Dose Preparation

Animal Identification

Body Weights

Vehicle Analysis

Clinical Observations

Dosing

Body Weights

Necropsy

Necropsy

Body Weights

Dosing

Necropsy

Data

Necropsy

Data

Data

Final Report
Review Date

$1 / 30 / 87$
$2 / 19 \& 20 / 87^{*}$
$2 / 19 \& 20 / 87^{*}$
$3 / 2 / 87^{*}$
$4 / 6 / 87^{*}$
$4 / 6 / 87^{*}$
$4 / 6 / 87^{*}$
$5 / 22 / 87$
$7 / 9 \& 10 / 87^{*}$
$7 / 30 / 87$
$9 / 4 / 87^{*}$
$11 / 12 / 87^{*}$
$11 / 12 \& 13 / 87^{*}$
$12 / 10 / 87^{*}$
$1 / 12 / 88^{*}$
$1 / 14 / 88^{*}$
$9 / 6,7 \& 22 / 89$

Date Findings Submitted in Writing to Study Director/Management
$2 / 11 / 87$
$3 / 10 / 87$
$3 / 10 / 87$
$3 / 4 / 87$
$4 / 7 / 87$
$4 / 7 / 87$
$4 / 7 / 87$
$5 / 27 / 87$
$7 / 14 / 87$
$8 / 3 / 87$
9/22/87
$11 / 12 / 87$
$11 / 13 / 87$
$1 / 1 / 88$
$1 / 18 / 88$
$2 / 1 / 88$
$9 / 22 / 89$

* Reviewed specificially for this study.

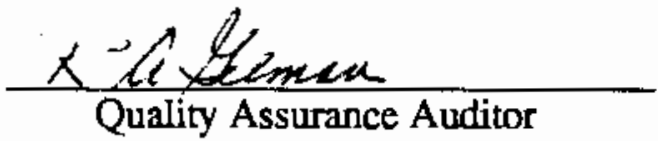

$\frac{9 / 20 / 89}{\text { Date }}$ 


\section{OFFSITE}

Commander (25)

U.S. Army Biomedical Research and Development Laboratory

Attn: SGRD-UBZ-RA

Fort Detrick

Frederic, MD 217D1-5010

Commander (2)

U.S. Army Medical Research and Development Command

Attn: SGRD-PLE

Fort Detrick

Frederick, MD 21701-5012

Commander (2)

U.S. Army Medical Research

Institute of Chemical Defense

Attn: SGRD-UV-ZB

Aberdeen Proving Grounds, MD 21010-5425

DOE/Richiand Operations Office

E.C. Norman/D.L. Sours (2)

Pacific Northwest Laboratory

Publishing Coordination

Technical Report Files (5)

L.B. Sasser (5)
Commander (1)

U.S. Army Medical Research and Development Command Attn: SGRD-RMI-S

Fort Detrick

Frederick, MD 217D1-5012

Chemical Effects Information Center (1)

Oak Ridge National Laboratory P.0. Box X

Oak Ridge, TN 37831

Defense Techincal

Information Center (2)

Attn: DTIC-FDAC

Cameron Station

Alexandria, VA 22304-6145 